\title{
MASTER
}

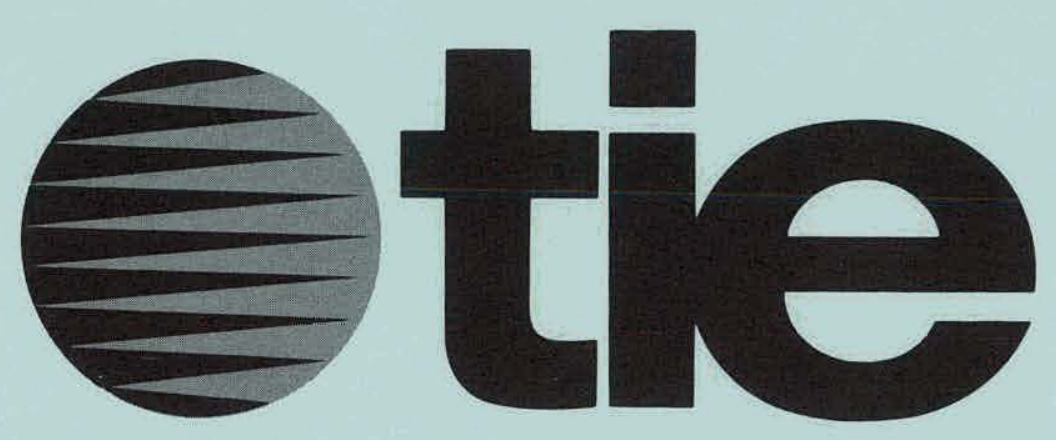

\section{THE ROLE OF TEMPERATE ZONE FORESTS IN THE WORLD CARBON CYCLE - PROBLEM DEFINITION AND RESEARCH NEEDS}

Report of a Workshop

Indianapolis, Indiana

March 21-22, 1979

\author{
Prepared for: \\ DEPARTMENT OF ENERGY \\ Office of Environment \\ Office of Health and \\ Environmental Research \\ Carbon Dioxide and Climate \\ Research Program \\ DOE Report No. DOE/EV/10040-1
}




\section{DISCLAIMER}

This report was prepared as an account of work sponsored by an agency of the United States Government. Neither the United States Government nor any agency Thereof, nor any of their employees, makes any warranty, express or implied, or assumes any legal liability or responsibility for the accuracy, completeness, or usefulness of any information, apparatus, product, or process disclosed, or represents that its use would not infringe privately owned rights. Reference herein to any specific commercial product, process, or service by trade name, trademark, manufacturer, or otherwise does not necessarily constitute or imply its endorsement, recommendation, or favoring by the United States Government or any agency thereof. The views and opinions of authors expressed herein do not necessarily state or reflect those of the United States Government or any agency thereof. 


\section{DISCLAIMER}

Portions of this document may be illegible in electronic image products. Images are produced from the best available original document. 


\title{
THE ROLE OF TEMPERATE ZONE FORESTS IN THE WORLD CARBON CYCLE -
}

\section{PROBLEM DEFINITION AND RESEARCH NEEDS}

\author{
Edited by \\ T. V. ARMENTANO and J. HETT
}

\author{
Work supported by \\ U.S. DEPARTMENT OF ENERGY, \\ OFFICE OF ENVIRONMENT, \\ under Contract No. 7
}

The Institute of Ecology (TIE)

Indianapolis, Indiana 46208

1979

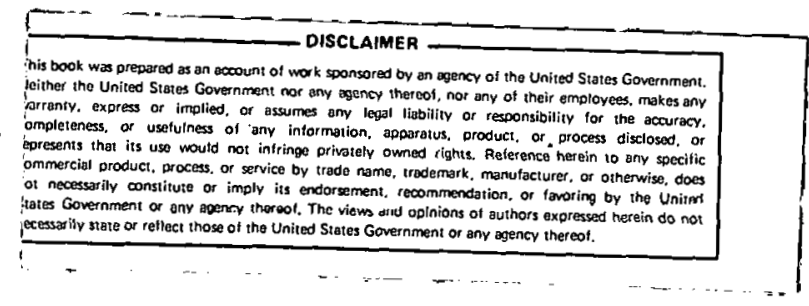

UISTRIBUTION OF THIS DOCUMENT IS UALIMITEO 


\section{PREFACE}

The continuing rise in the $\mathrm{CO}_{2}$ content of the atmosphere has produced concern that in the next half-century, climatic, ecological and societal effects may occur throughout the world which will not easily be reversed. This prospect has encouraged a critical assessment of the many elements of the global carbon cycle and the influence of man on it. The role of the terrestrial biosphere has been underscored by recent evidence that reduction of the world's biota may be adding as much or more carbon to the atmosphere as combustion of fossil fuels.

The diversity of world ecosystems, and the lack of data on carbon content in many of them, have led to different interpretations of how much the terrestrial biosphere contributes to carbon accumulation in the atmosphere. A detailed review is needed of the principal elements of biospheric influence on the carbon cycle, of where the accumulating atmospheric carbon is originating, and of the options there may be to control it.

The Office of Carbon Dioxide Effects Research and Assessment of the U.S. Department of Energy has funded The Institute of Ecology to evaluate three terrestrial biospheric components which may be important in the world carbon cycle. These components are: the temperate zone forest, particularly over the past 100 years; organic soils of the world; and freshwater systems subject to eutrophication. From 10 to 12 researchers have participated in each panel. Data review, problem definition and recommendations for research have been the focus in each workshop. The results reported here cover the temperate forest component.

Thomas $v$. Armentano

August 1979 
TABLE OF CONTENTS

Page

EXECUTIVE SUMMARY. .................

INTRODUCTION . . . . . . . . . . . . . . . . . I

CURRENT TRENDS IN TEMPERATE ZONE FORESTS . . . . . . . . . 2

North America . . . . . . . . . . . . . . 2

United States................. 3

Canada .................. 5

Europe and Asia . . . . . . . . . . . . 5

REGIONAL ANALYSES OF FOREST CARBON EXCHANGE. . . . . . . . . 9

Southeastern United States. . . . . . . . . . . 9

New England................. 20

THE NORTH TEMPERATE ZONE FOREST CARBON POOL. . . . . . . . . 22

Policy Aspects of a Temperate Zone Forest Research Program. . . 26

DATA NEEDS AND RESEARCH RECOMMENDATIONS. . . . . . . . . . 27

Limitations to the Analysis of Temperate Forest Carbon

Exchange . . . . . . . . . . . . . 27

Recommendations for Research. . . . . . . . . . . 34

WORKSHOP CONCLUSIONS . . . . . . . . . . . . . 37

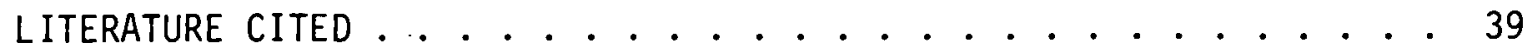

APPENDIX I: Workshop Participants ........... 45

APPENDIX II: Growth Trends in Commercial Forests of North

America - A Regional Analysis............ 47

APPENDIX III: The Influence of Civilization Upon European

and Asian Forests ............... 68 


\section{EXECUT IVE SUMMARY}

This report presents the proceedings of a workshop on carbon uptake and losses from temperate zone forests held March 23-24 in Indianapolis, Indiana. The goals of the workshop were to analyze existing data on growth and utilization of the temperate zone forest carbon pool and to identify further research needs in relation to the role of temperate forests in the global carbon cycle.

Total standing stock and growth recovery transients were examined for most of the temperate region over a period from pre-settlement times to the present, with emphasis on the last three decades. Because of data availability, certain regions and topics were covered more in detail than others. The following are the major topics and findings:

- Forest inventory data from most of the commercial timberlands of the north temperate zone suggest these forests have functioned over the past several decades as an annual sink for about $10^{9}$ metric tons of carbon. Thus, net growth of these forests has withdrawn carbon from the atmosphere at a rate equivalent, approximately, to 50 percent of the annual rise in atmospheric carbon. Various data inadequacies make this estimate probably no more precise than plus or minus half of the value.

- Analysis of growth and vegetation changes in New England and the southeastern United States shows that forest biomass has partly recovered since extensive clearing took place in the 18th and 19th centuries. This regrowth represents a net withdrawal of carbon (carbon sink) from the atmosphere in recent decades, al though the difference in pool size between present and original forests means that, in the longer term, the two regions have functioned as carbon sources.

- The sparse available data indicate large releases of carbon from litter and soil pools can accompany timber removal. Carbon accumulation in forest soils, however, can also function as a major sink for atmospheric carbon. The accumulation of carbon in wood following a period of cultivation (or other forest disturbance) may differ significantiy, however, from the recovery sequence of soil carbon. Additional study of the carbon in litter and soil is needed for various forest types and ages, particularly as influenced by differences in land use and fires.

- Growth dynamics of forests in Siberia, the largest timber volume in the temperate zone, and in China, where reforestation could lead to development of a large carbon sink, are inadequately known and must be fully documented if the role of these regions in the global carbon balance is to be defined. 
- Wood products such as building materials, railroad ties, mine pitprops and paper products contain large quantities of carbon, originally fixed in forests, but then not returned immediately to the atmosphere. Little is known of the volume of the materials currently stored, or of their average longevity. An inventory of carbon persisting in durable wood products is needed to complete understanding of the influence of forest harvests upon the carbon cycle.

- Since forests store more carbon than any other land system, the rate of conversion of forested (or non-forested) land can, itself, be a major influence on carbon source (or sink) relationships. Data on land conversion rates should be improved, particularly where afforestation is extensive, or where clearing and reversion to forest occur simultaneously.

- High-latitude peatlands represent a large carbon pool for which few data exist. These systems have been classified with the boreal forests of the temperate zone, probably resulting in an underestimate of total carbon content. Spatial variation in the carbon pool size is high, and the importance of fire and paludification inadequately known. Improved estimates of carbon in relation to rates of paludification, wildfires, and storage of detritus in high-latitude peatlands is needed from scientists in Canada, the United States, Scandinavia, and the U.S.S.R.

The workshop participants have recommended a series of research initiatives to increase resolution of the problem areas described above within three years - a schedule that will allow policy analysts an opportunity to incorporate findings into energy decisions by the mid 1980's. For some of the research, an intensive literature review and workshops involving forest research leaders from the principal temperate zone nations would provide the needed information. In other areas, new field research will be required.

Two questions of a policy nature were reviewed, both having major ecological implications: One examined whether temperate zone forests can be managed as a carbon sink, and what silvicultural methods or nutrient additions would be needed to divert more carbon into long-term wood storage. Another asked whether a substantial portion of the total forest production could serve as a fuel source, thereby reducing reliance on fossil fuels. The answers to both questions are cautiously affirmative, within the limits of data available. However, these answers can be given with reasonable confidence only for certain well-studied forests types. 


\section{INTRODUCTION}

Recent studies have shown that the exchanges of carbon between biological components and the atmosphere are critical for balancing the world carbon budget (01son et al. 1978, Siegenthaler and Oeschger 1978). Estimates of the contribution of carbon from the world's continental ecosystems range from a net release to the atmosphere of up to $18 \times 10^{15} \mathrm{~g} \mathrm{C}$ per year (Woodwell et al. 1978) to a possible net uptake from the atmosphere (Revelle and Monk 1978). Bolin (1977) believes there is an annual net release of about $1 \times$ $10^{15} \mathrm{~g}$ of carbon from the biota, and Stuiver (1978) estimates an ayerage annual release of biospheric carbon to the atmosphere of $1.2 \times 10^{15} \mathrm{~g} \mathrm{C}$ between 1850 and 1950, with a smaller release since then.

Since forests comprise about $90 \%$ of the biomass of the terrestrial biotic pool, changes in forest area and pool size determine whether or not the biota function as a source or sink for atmospheric $\mathrm{CO}_{2}$. Through photosynthesis and respiration, forests also transfer more carbon to and from the atmosphere than any other biotic component, although the net exchange can be relatively small when these two physiological processes counter-balance one another. Recent reviews have concentrated on the tropical forests because of the large biomass (53\% of total forest biomass) and the continuing reduction of tropical forest area and volume. Carbon may be released from these systems in quantities which approach or even exceed the annual fossil fuel increment (Woodwell et al. 1978).

The second largest biotic carbon pool is the temperate zone forests, consisting of deciduous, mixed coniferous-deciduous, temperate coniferous, and boreal forests throughout the world. Most of this vegetation exists in the north temperate zone between $30^{\circ}$ and $60^{\circ} \mathrm{N}$ latitude, a band of the earth which includes much cultivated land derived from forest areas. The temperate zone forests differ from the tropical forests in that most of the forest destruction occurred in the past (from about 50 to 200 years ago in North America, ranging back 2,000 to 5,000 years ago in the Far East).

Since the period of major temperate forest losses, historical events and natural processes have had the effect of incorporating more carbon into the forest pool, particularly over the last 50 years. These processes include: a) the expansion of forests through abandonment of agriculture and by afforestation, b) net regrowth of forest stands following cuttings in the late 19th and early 20th centuries (in North America), c) systematic control of wildfires, and d) forest management leading to higher growth rates in certain areas. In Europe, forest grazing by domestic animals generally has ceased over the last 50 years (Bol in 1977), while in both Europe and North America, the use of wood for fuel has declined (Bramryd 1979).

Thus, the question of whether the recent trends in temperate forest growth are significant for the global carbon budget was identified as the central issue for an inter-institutional evaluation workshop conducted by The Institute of Ecology. The degree of uncertainty and varying interpre- 
tations in recently published papers concerning temperate forests indicated a need to seek a consensus among specialists in temperate forest growth and biomass dynamics.

The participants were asked to evaluate data on forest carbon dynamics with respect to the question of whether temperate zone forests have become a net carbon sink since the major. North American forest cuttings. The following workshop. goals were established:

1. Determine whether sufficient data are, available, or are being collected in present research programs, to permit a reliable, quantitative determination of the contribution of temperate zone forests to the net global carbon exchange.

2. If sufficient data exist, decide if a separate coordination program of data synthes is should be undertaken in order to analyze the importance of temperate zone forests.

3. Reach a consensus on whether or not existing data are sufficiently assumption-free to determine the importance of temperate zone forests in the global carbon exchange.

4. If there is a clear need for new data, recommend an action plan of further research to meet this: need.

\section{CURRENT TRENDS IN TEMPERATE ZONE FORESTS}

Existing data on temperate zone forests as carbon pools were reviewed by participants in the principal geographic areas of the temperate zone. After data presentation, problems of interpretation were discussed by the entire workshop. This section presents a compilation of data on forest biomass in different parts of the temperate zone. A review of the sub-. continental forest pools is presented first, followed by a more detailed approximation of the forest trends in two sections of the United States. For other regions of the U.S. and Canada, for which primarily commercial forest inventories are available, data summaries are presented in Appendix II. Participants agreed that insufficient data were available to provide a regional breakdown of forest dynamics in Europe and Asia. Problems of interpretation and limitations in the data will be discussed in the section on Data Limitations and Recommended Research.

\section{North America* :}

Because of different inventory and classification systems between the United States and Canada, the forests of these countries are most conveniently considered separately. Although certain forest communities of Mexico, especially those of the two Sierra Madre Mountain chains, are in many ways an extension of the deciduous and mixed forests of the U.S., their areal extent

\footnotetext{
* Based on a presentation by C. W. Ralston of Duke University.
} 
is relatively small, and they have not been considered in this discussion.

United States

For the U.S., the most complete source of data is the U.S. Forest Service which has conducted surveys of U.S. commercial forests for nearly 40 years (U.S.D.A. 1.978). The Forest Service maintains permanent sample plots as part of a Continuous Forest Inventory (CFI) :throughout the country. Forest mensurational data including timber volume, stemwood increment, and removal and mortality during the sampling interval, are taken at approximately 10year intervals. Clearing of forests can also be estimated from these plots. Data have been published for U.S. forests as a whole for 1952, 1962, 1970 and 1976.

The CFI statistics which can be used to estimate the storage or release of carbon from commercial forests are:

1. Net annual growth - The increase in stemwood volume during a specified year. Components of net annual growth include the increment in net bole volume of trees at the beginning of the specified year surviving to its end, plus the net bole volume of trees that died during the year, minus the net volume of trees that became rough or rotten trees during the year.

2. Removals - Volume of timber removed from the growing stock inventory, including timber products, logging residues, and other removals such as occur by land clearing.

Volumes listed for growth and removals in forest surveys include those for all growing stock having a minimum diameter of 5 inches at a one-foot stump. Volume is measured to a top diameter of 4 inches outside bark.

Total net volume estimates for the U.S. indicate a surplus of growth over removals for, the past 24 years (Table 1). In the section designations used in Table 1, North includes the New England, mid-Atlantic, Lake and central states; South includes the south-Atlantic and the Gulf states; Rocky Mounta in includes northern and southern Rocky Mounta in states; and Pacific Coast comprises the states bordered by the Pacific Ocean (including Alaska). The positive growth trend holds for all forest regions except the Pacific Coast, where there is a backlog of mature and over-mature stands with annual growth and mortality nearly equal. Consequently, harvest of old growth can be expected to show a net negative growth until such time as second-growth stands become dominant in the inventory. The surplus of growth over drain in other regions, particularly the eastern U.S., results from past cutting practices which have produced large areas of immature stands of low density. The selective culling of eastern hardwood forests has created a large surplus of growth over removals for hardwoods. The surplus growth margin for softwoods is much smaller.

The future carbon storage potential of U.S. forests can be estimated from U.S. Forest Service data on actual and potential net annual growth 
Table 1. Forest growth and removals as recorded by the U.S. Forest Service from their Continuous Forest Inventory plots. Data include all sound growing stock with a minimum diameter of $12.5 \mathrm{~cm}$ ( 5 inches) at a $30 \mathrm{~cm}$ ( 12 inch) stump.. Inside bark volume is measured to a top diameter of $10 \mathrm{~cm}$ (4 inches) outside bark. Cut means all removals from growing stock volume including timber products, logging residues and other losses such as land clearing.

\begin{tabular}{|c|c|c|c|c|c|}
\hline $\begin{array}{l}\text { Forest } \\
\text { Inventory } \\
\left(10^{6} \mathrm{~m}^{3}\right)^{\star}\end{array}$ & North & South & $\begin{array}{c}\text { Rocky } \\
\text { Mountains }\end{array}$ & $\begin{array}{c}\text { Pacific } \\
\text { Coast }\end{array}$ & Total \\
\hline $\begin{array}{l}1976 \\
\text { Growth } \\
\text { Cut } \\
\text { Net Increment }\end{array}$ & $\begin{array}{r}168 \\
77 \\
91\end{array}$ & $\begin{array}{l}307 \\
186 \\
121\end{array}$ & $\begin{array}{l}48 \\
24 \\
24\end{array}$ & $\begin{array}{r}97 \\
121 \\
-24\end{array}$ & $\begin{array}{l}620 \\
409 \\
211\end{array}$ \\
\hline $\begin{array}{l}1970 \\
\text { Growth } \\
\text { Cut } \\
\text { Net Increment }\end{array}$ & $\begin{array}{r}150 \\
72 \\
78\end{array}$ & $\begin{array}{l}2.71 \\
184 \\
87\end{array}$ & $\begin{array}{l}43 \\
25 \\
18\end{array}$ & $\begin{array}{r}92 \\
118 \\
-26\end{array}$ & $\begin{array}{l}557 \\
399 \\
158\end{array}$ \\
\hline $\begin{array}{l}1962 \\
\text { Growth } \\
\text { Cut } \\
\text { Net Increment }\end{array}$ & $\begin{array}{r}135 \\
58 \\
77\end{array}$ & $\begin{array}{l}221 \\
156 \\
65\end{array}$ & $\begin{array}{l}37 \\
\frac{21}{16}\end{array}$ & $\begin{array}{r}77 \\
102 \\
-25\end{array}$ & $\begin{array}{l}470 \\
338 \\
132\end{array}$ \\
\hline $\begin{array}{l}1952 \\
\text { Growth } \\
\text { Cut } \\
\text { Net Increment }\end{array}$ & $\begin{array}{r}116 \\
59 \\
57\end{array}$ & $\begin{array}{l}183 \\
161 \\
22\end{array}$ & $\begin{array}{l}33 \\
15 \\
18\end{array}$ & $\begin{array}{r}65 \\
100 \\
-35\end{array}$ & $\begin{array}{r}396 \\
\frac{335}{61}\end{array}$ \\
\hline
\end{tabular}

$\star 1 \mathrm{~m}^{3}=35.31 \mathrm{cu} . \mathrm{ft}$. 
rates (Table 2). Potential growth rates represent culmination of mean annual increment of fully stocked natural stands of the dominant commercial species at survey plot locations. The potential rates are averaged over five site-productivity classes and are for the species that are actually present, not those that would have highest growth rates for the sites in question. On this conservative basis, the mean actual growth rate for the U.S is $50 \%$ of the potential rate, i.e., about one-half instead of one cord $\mathrm{ac}^{-1} \mathrm{yr}^{-1}$. Current actual growth rate of U.S. forests thus represents a growing stock level at about one-half of full stocking. Therefore, there is a potential for additional carbon storage for a number of years which depends on the increase in demand for timber products. U.S. Forest Service (1973) forecasts of supply and demand indicate a crossover point between cut and growth at about 1990, if price inflation is based on 1970 prices.

Canada

Forest inventory compilations for Canada have been less frequent and less uniform in methodology than those of the United States. Total forest standing crop and removal volumes are, however, expressed uniformly among the provinces. In Canada, wood volume data include stems with a minimum diameter that varies with province from 7.9 to $17.5 \mathrm{~cm}$ at $1.4 \mathrm{~m}$ height. Stumps are included in two provinces while stumps taller than 15 to $30 \mathrm{~cm}$ are excluded in the other provinces. The minimum top diameter included in the merchantable stem also varies (Bowen 1978). However, in all provinces, net annual growth for immature stands is defined as yield table values of "mean annual increment by site class at rotation age". Overall control of harvesting of public forests, which comprise over $90 \%$ of total forest land in Canada, is made by determining "allowable annual cuts" from sustained yield management formulae that vary with province. An approximation of the "growth" and removal balance for Canadian forests gives a surplus of $99 x$ $10^{6} \mathrm{~m}^{3}$ of timber volume (Table 3 ). The surplus is the net difference between calculated allowable cut and actual harvest volume and as such may be a misestimate of the true net growth surplus. The direction of bias depends on the ratio of immature to old-growth stands. The net volume surplus probably represents a net growth surplus if immature stands occupy $30 \%$ or more of the forested area.

\section{Europe and Asia*}

Forest resource data are very uneven for the Eurasian continent, particularly for the U.S.S.R., China, eastern Europe and western Asia. Data are most common for western Europe, particularly member nations of the European Economic Community. In this region of $31 \times 10^{6}$ ha of forest land, forest areas were regularly exploited for centuries and only about $20 \%$ of the landscape is forested now, although climate and soils are conducive to forest development (Table 4). Throughout Europe, as well as in much of Asia except Siberia, forests were destroyed by war, overcutting, fire, erosion, and grazing (Appendix III). Only in Scandinavia and Siberia have natural forests continued to dominate large sections of the landscape.

*Based on a presentation by T. V. Armentano of TIE. 
Table 2. Current and potential net growth in the United States by ownership class and section (in $\mathrm{m}^{3}$. ha- ${ }^{-1}$ ).*

\begin{tabular}{|c|c|c|c|c|c|c|}
\hline Section & $\begin{array}{c}1970 \\
\text { and } \\
\text { Potential }\end{array}$ & $\begin{array}{c}\text { National } \\
\text { Forest }\end{array}$ & $\begin{array}{l}\text { Other } \\
\text { Public }\end{array}$ & $\begin{array}{l}\text { Forest } \\
\text { Industry }\end{array}$ & $\begin{array}{l}\text { Other } \\
\text { Private }\end{array}$ & $\begin{array}{c}\text { All } \\
\text { Ownerships }\end{array}$ \\
\hline North & $\begin{array}{c}1970 \\
\text { Potential }\end{array}$ & $\begin{array}{l}0.19 \\
0.32\end{array}$ & $\begin{array}{l}0.16 \\
0.29\end{array}$ & $\begin{array}{l}0.20 \\
0.35\end{array}$ & $\begin{array}{l}0.14 \\
0.34\end{array}$ & $\begin{array}{l}0.15 \\
0.32\end{array}$ \\
\hline South & $\begin{array}{c}1970 \\
\text { Potential }\end{array}$ & $\begin{array}{l}0.27 \\
0.34\end{array}$ & $\begin{array}{l}0.22 \\
0.35\end{array}$ & $\begin{array}{l}0.26 \\
0.40\end{array}$ & $\begin{array}{l}0.20 \\
0.39\end{array}$ & $\begin{array}{l}0.22 \\
0.38\end{array}$ \\
\hline $\begin{array}{l}\text { Rocky } \\
\text { Mountains }\end{array}$ & $\begin{array}{c}1970 \\
\text { Potential }\end{array}$ & $\begin{array}{l}0.11 \\
0.31\end{array}$ & $\begin{array}{l}0.11 \\
0.27\end{array}$ & $\begin{array}{l}0.23 \\
0.34\end{array}$ & $\begin{array}{l}0.12 \\
0.24\end{array}$ & $\begin{array}{l}0.12 \\
0.30\end{array}$ \\
\hline $\begin{array}{l}\text { Pacific } \\
\text { Coast } \star \star\end{array}$ & $\begin{array}{c}1970 \\
\text { Potential }\end{array}$ & $\begin{array}{l}0.15 \\
0.43\end{array}$ & $\begin{array}{l}0.31 \\
0.49\end{array}$ & $\begin{array}{l}0.31 \\
0.52\end{array}$ & $\begin{array}{l}0.28 \\
0.46\end{array}$ & $\begin{array}{l}0.24 \\
0.48\end{array}$ \\
\hline Total & $\begin{array}{c}1970 \\
\text { Potential }\end{array}$ & $\begin{array}{l}0.15 \\
0.37\end{array}$ & $\begin{array}{l}0.19 \\
0.35\end{array}$ & $\begin{array}{l}0.25 \\
0.43\end{array}$ & $\begin{array}{l}0.17 \\
0.36\end{array}$ & $\begin{array}{l}0.18 \\
0.37\end{array}$ \\
\hline
\end{tabular}

$\star 1 \mathrm{~m}^{3} \cdot \mathrm{ha}^{-1}=14.2913 \mathrm{cu}$. ft. per acre.

$\star \star$ Exclusive of Alaska. 
Table 3. Estimated allowable timber cut and actual removals for Canada in 1977 (Reed \& Associates, 1978). This study evaluated 238 $x 10^{6}$ ha of forest land "suitable for harvest", excluding 6.9 $\times 10^{6}$ ha productive reserved forest, and $77.3 \times 10^{6}$ ha of. forest "not suitable for regular harvest".

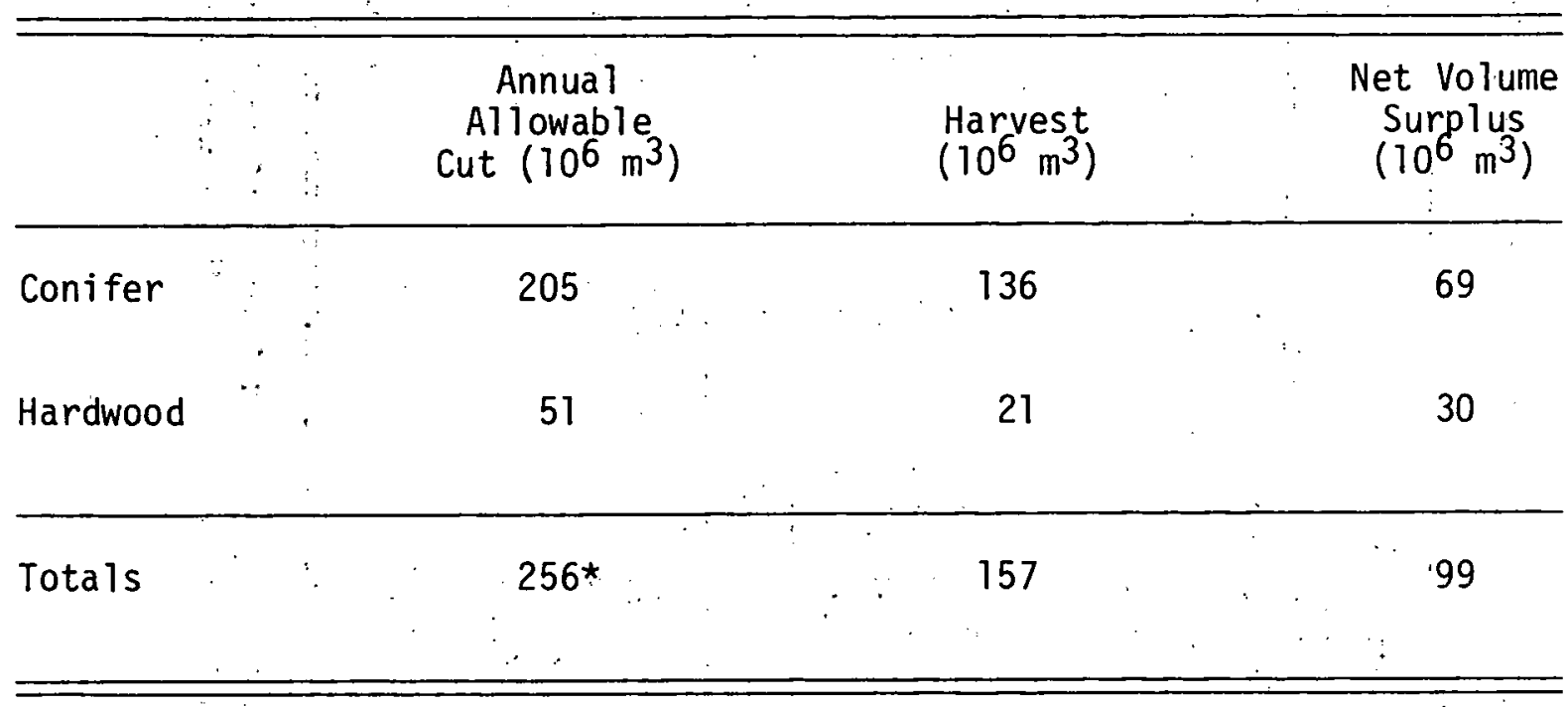

* In an update of thesse data, Bowen (1978) estimated the annual allowable cut at $.276 \times 10^{6} \mathrm{~m}^{3}$ as of March 31, 1977. 
Table 4. Forest stands of selected European and Asian countries $\left(10^{6} \mathrm{ha}\right)$.

\begin{tabular}{|c|c|c|c|c|c|c|}
\hline Country & $\begin{array}{l}\text { Land Area } \\
\left(10^{6} \mathrm{ha}\right)\end{array}$ & $\begin{array}{c}\text { Forest Area } \\
\left(10^{6} \text { ha) }\right. \\
\text { (\% regularly } \\
\text { exploited) }\end{array}$ & $\begin{array}{c}\% \\
\text { Forest Area } \\
\text { Coniferous }\end{array}$ & $\begin{array}{l}\text { Total } \\
\text { Timber } \\
\text { Resources } \\
\left(10^{9} \mathrm{~m}^{3}\right)\end{array}$ & $\begin{array}{l}\% \text { Resources } \\
\text { Coniferous }\end{array}$ & Source \\
\hline $\begin{array}{l}\text { Belgium/ } \\
\text { Netherlands/ } \\
\text { Luxembourg } \\
\text { German FDR } \\
\text { Denmark } \\
\text { France } \\
\text { Italy } \\
\text { Ireland/U.K. }\end{array}$ & $\begin{array}{r}6.98 \\
24.86 \\
4.30 \\
54.91 \\
30.12 \\
31.43\end{array}$ & $\begin{array}{r}0.92(94) \\
\\
7.21(97) \\
0.47(93) \\
14.00(67) \\
6.19(97) \\
2.13(84)\end{array}$ & $\begin{array}{l}69 \\
63 \\
29 \\
21 \\
76\end{array}$ & $\begin{array}{l}0.11 \\
\\
1.02 \\
0.045 \\
1.31 \\
0.35 \\
0.17\end{array}$ & $\begin{array}{l}55 \\
71 \\
49 \\
37 \\
36 \\
50 .\end{array}$ & $\begin{array}{l}\text { Commission of the } \\
\text { European Communities } \\
\text { (1976) }\end{array}$ \\
\hline EEC & 152.60 & $30.92(83)$ & 42 & 3.00 & 50 & \\
\hline $\begin{array}{l}\text { East Central Europe } \\
\text { Europe (except USSR) } \\
\text { Sweden } \\
\text { Finland } \\
\text { USSR }\end{array}$ & $\begin{array}{r}457.00 \\
47.10 \\
33.70 \\
2220.00\end{array}$ & $\begin{array}{r}35.80 \\
169.001 \\
23.503 \\
20.56^{3} \\
765.0{ }^{\star}\end{array}$ & $\begin{array}{l}41 \\
511 \\
822 \\
812 \\
75\end{array}$ & $\begin{array}{r}13 \cdot 40^{1} \\
2.36^{2} \\
1: 40-1.50^{2} \\
73-79^{4}, 5\end{array}$ & $\begin{array}{r}62 \\
. \\
\therefore 84\end{array}$ & $\begin{array}{l}\text { Teclaff (1956) } \\
\text { 1 Cliff (1973) } \\
2 \text { Reed \& Assoc. (1978) } \\
3 \text { Bramryd (1979) } \\
\text { 4Skoggstyrelsen in } \\
\text { Bramryd (1979) }\end{array}$ \\
\hline $\begin{array}{l}\text { China } \\
\text { Japan }\end{array}$ & $\begin{array}{l}956.00 \\
100.00\end{array}$ & $\begin{array}{r}100.00^{2} \\
25.10^{6}\end{array}$ & $42^{1}$ & $2.09^{6}$ & $52^{i}$ & $\begin{array}{l}5 \text { Sutton }(1975) \\
6 \text { Forster }(1978)\end{array}$ \\
\hline
\end{tabular}

* Closed woodland (crown cover $\geq 20 \%$ of ground surface). Persson in Eckholm (1979) reports on additional $280 \times 10^{6}$ ha of open woodland (tree cover 5\%-19\%). Other estimates of U.S.S.R. forest area range from 681-1131 × $10^{6}$ ha (Sutton 1975). 
Since the time of major forest devastation in Europe, especially since World War II, forest lands have been expanded continuously primarily by plantation establishment (Table 5). Conifers are preferred in most countries (e.g., 70\% of the total afforested area in the German Federal Republic and 94\% of the afforested area of the United Kingdom) except in Italy where eucalyptus and poplar species are the principal trees used. Nearly all of Europe except high mountains and the extreme north was originally occupied by deciduous forests, but planted conifers are replacing the oak, beech, hornbeam and maple. Afforestation in Scandinavia includes reclaiming of peatland by drainage. In the European Economic Community there has been about a $5 \%$ increase in net forest area by afforestation. This is equivalent to an increase of 67,700 ha per year from 1950 to 1973 .

In China and South Korea, reports indicate that large-scale tree planting programs have been undertaken but no details are available on the success of the programs or on whether the goals have been principally for firewood, erosion control or timber production (Eckholm 1979).

About $33 \%$ of Japanese forest land has been planted, with more than $75 \%$ of the plantations begun after World War II (Forster 1978). Only about 5\% of the plantation trees exceed 60 years of age. In contrast, about onethird of the natural forests, which often are found in remote regions, are older than 60 years. The total growing stock is about $2 \times 10^{9} \mathrm{~m}^{3}$, equally divided between softwoods and hardwoods. Cutting in Jąpan dropped sharply in the mid-1970's from a 1969-71 average of $46 \times 10^{6} \mathrm{~m}^{3}$. The cutting.rate is expected to rise over the next five years, but to fall short of the maximum allowable cut of over $80 \times 10^{6} \mathrm{~m}^{3}$ (Forster 1978).

Standing timber in Europe has increased as net growth exceeded cutting in spite of the fact that except for Sweden and Finland, Europe imports most of its wood needs (Table 6). The estimates for the total timber resources of the U.S.S.R., where over half of the world's softwood forests lie, vary, but there is general agreement that there is a great excess of wood volume, most of it in the inaccessible taiga.

Estimates of the annual net increment vary from 450 to $618 \times 10^{6} \mathrm{~m}^{3}$ (Sutton 1975). A conservative value has been chosen for estimating the net increase in standing timber (Table 6$)_{3}$ The exploitable forest in the U.S.S.R. has been reported as about $47 \times 10^{9} \mathrm{~m}^{3}$ - just over $60 \%$ of the total national timber resource (Reed and Associates 1978). Two Russian estimates of the timber volume of forests actually in use or centrally managed are 42.8 and $53.4 \times 10^{9} \mathrm{~m}^{3}$ (Sutton 1975).

\section{REGIONAL ANALYSES OF FOREST CARBON EXCHANGE \\ Southeastern United States*}

A major question centers on whether certain regions of the temperate zone now serve (or did so in the past) as sources or sinks for atmospheric

* Based on an analysis by W. F. Harris of Oak Ridge National Laboratory. 
Table 5. Changes in forest area in selected European and Asian countries (in 10 ${ }^{3}$ ha) 1950-1973.

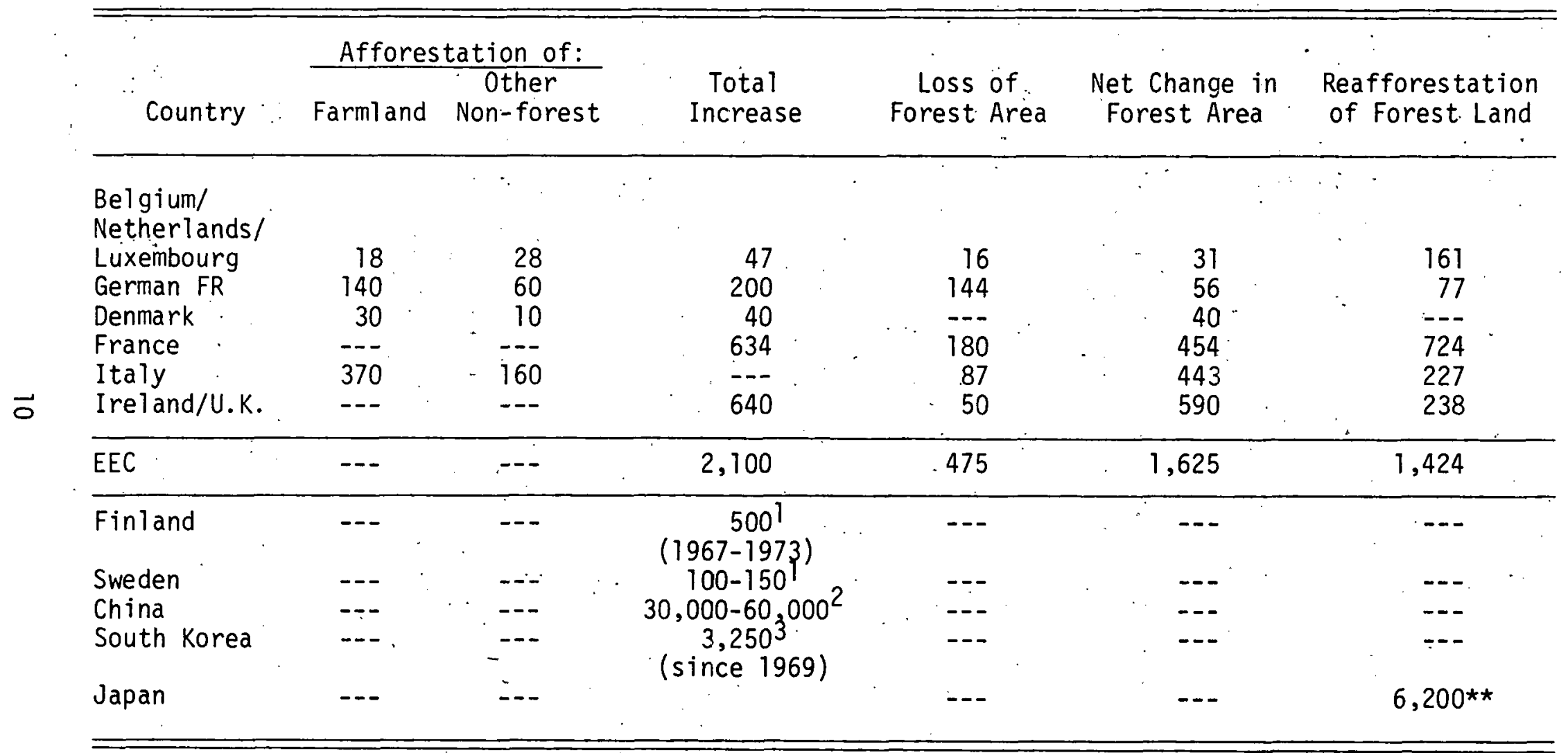

Source: Commission of the European Communities (1976) except where noted. 1-Bramryd, T. (1979); 2-Persson, R. (1978) in Eckholm (1979); 3-South Korea Government release, reported in Eckholm (1979).

*For all of Europe outside U.S.S.R., $5.8 \times 10^{6}$ ha were expected to be planted by 1967 (Unasyiva 1966). **. Calculated from Forster (1978). 
Table 6. Annual wood increment and cuttings in selected European and Asian countries.

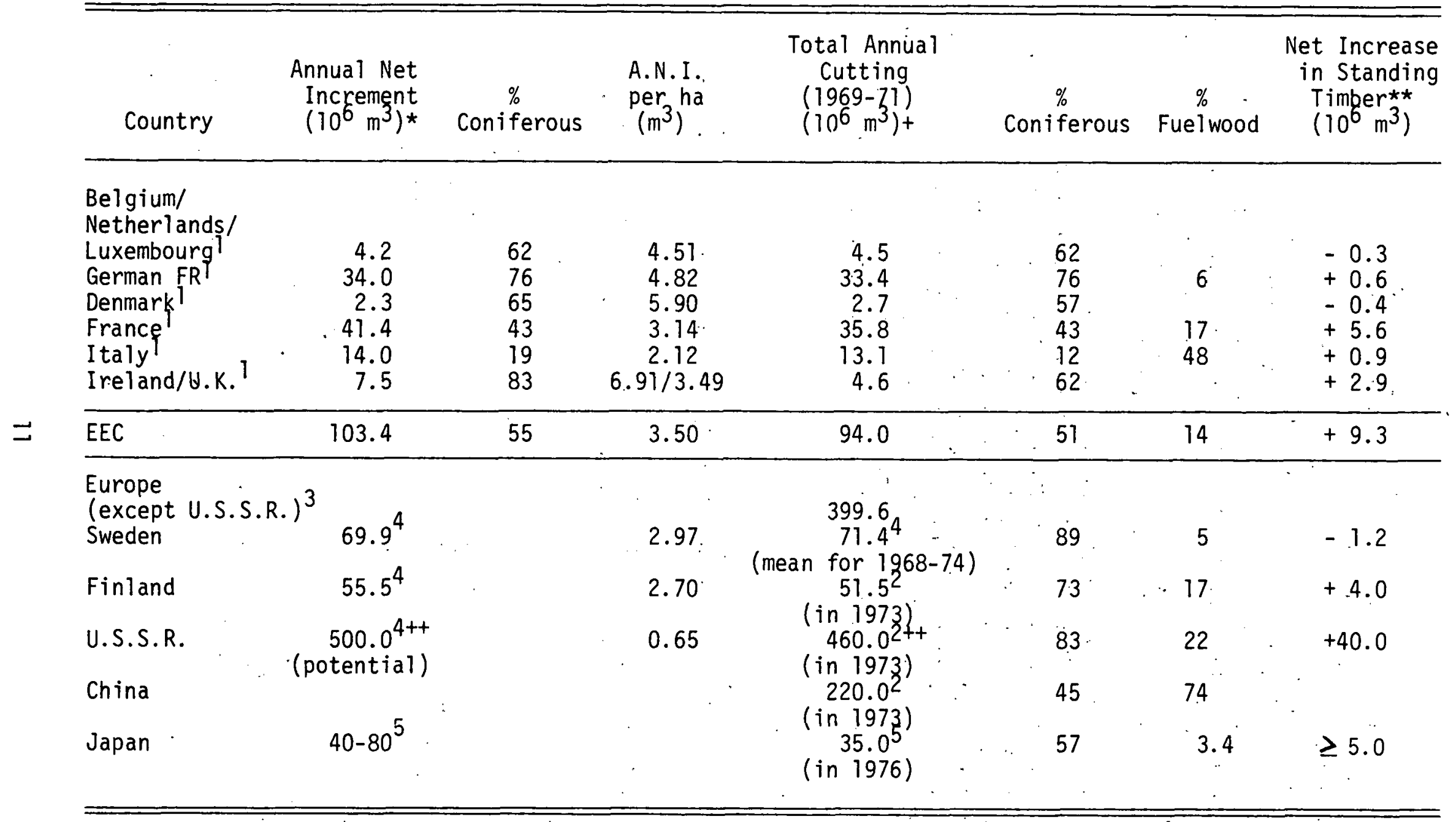

Sources: 1-Commission of the European Communities (1976); 2-Skoggstyrelsen (1976) in Bramryd (1979); 3-Cliff (1973); 4-Reed \& Associates (1978); 5-Forster (1978).

*With bark/**Annual net increment-total annual cutting/+Under bark data from Skoggstyrelsen or Commission of the European Communities 1.2 to account for bark/++Estimates of annual increment or allowable annual cut range from $450-618 \times 10^{6} \mathrm{~m}^{3}$, while official data for annual cutting (under bark) range from $351-383 \times 10^{6} \mathrm{~m}^{3}$ $\mathrm{yr}^{-1}$ from 1960 to 1972 (Sutton 1975). 
$\mathrm{CO}_{2}$. Using the southeastern United States as an example illustrates: 1) the assumptions that must be made or refined in calculating a regional carbon mass balance and the uncertainties associated with these assumptions, 2) the overall fluxes of $\mathrm{CO}_{2}$, and 3) the implications of deforestation in this region for atmospheric $\mathrm{CO}_{2}$ content. The present stage of assessing whether an entire region is a source or sink for atmospheric $\mathrm{CO}_{2}$ is an elaboration of a reasoning process, sparsely supported by limited specific site studies rather than a rigorous calculation based on accepted facts clearly known for wide areas. Nonetheless, identifying needed parameters and using "reasonable" estimates can identify ways to improve our data base at a regional, and eventually a global, scale.

Analysis of the carbon balance of the southeastern U.S. is based on the Conservation Needs Inventory (1967) and the county survey of Klopatek et al. (1979). The area considered is summarized in Table 7 . These vegetation types (Küchler 1964) generally encompass the region for which land use maps (circa 1967) are available (Figures 1-3). Original areas and the proportion of present vegetation types are shown in Table 7 . The period of settlement for most of the area was from 1800 to 1967 . Much clearing of Atlantic Coast areas occurred earlier, however; thus estimates of carbon release rates may be exaggerated. Net carbon loss may also be exaggerated if the reduction of virgin forests by fire was important in the pre-settlement forests.

\section{Carbon Losses}

Carbon losses include direct harvest by land clearing, selective harvest in residual stands, erosion and decay losses of humus and litter, and root decay.

Carbon_Lost in_Clearing. Of the original forest area (Table 7), $95 \times 10^{6}$ ha are no longer forest. If the original above-ground pool of carbon was 150. tons $\mathrm{ha}^{-1}$, clearing released $1.43 \times 10^{10} \mathrm{t}$ of carbon by oxidation. (Regrowth on these areas, e.g., of crops or old field biomass, is neglected for the present.) of the remaining forests. ( $99 \times 10^{6}$ ha as of 1967), the average hectare may have lost $100 \mathrm{t} C$ from selective harvest and death, a figure consistent with the current standing. biomass of stands known to have been disturbed from the early 1800's (Delcourt and West, personal communication). Thus, harvest and death in residual stands account for $9.93 \times 10^{9} \mathrm{t} \mathrm{C}$. Clearing plus residual harvest, then, total $2.42 \times 10^{10} \mathrm{t} \mathrm{C}$. If this loss were equally distributed over the 167-year period, the annual

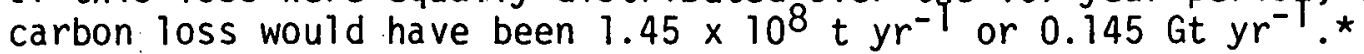

Soil Carbon Losses. Based on an estimate of agricultural and pasture land area of $7.09 \frac{9}{10} \frac{8}{h a}$ and assuming $100 \mathrm{t} \mathrm{ha}$ loss from cultivation, carbon loss via oxidation (and erosion) would be

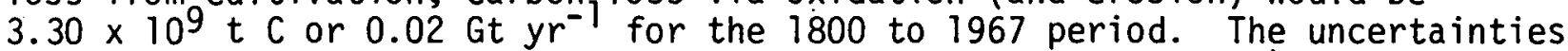
in this calculation are: 1) the value of soil organic matter, 2) the rate of loss, and 3) the estimate of land area affected and how this area changed

* A gigaton equals $10^{9}$ metric tons or $10^{15} \mathrm{~g}$. 


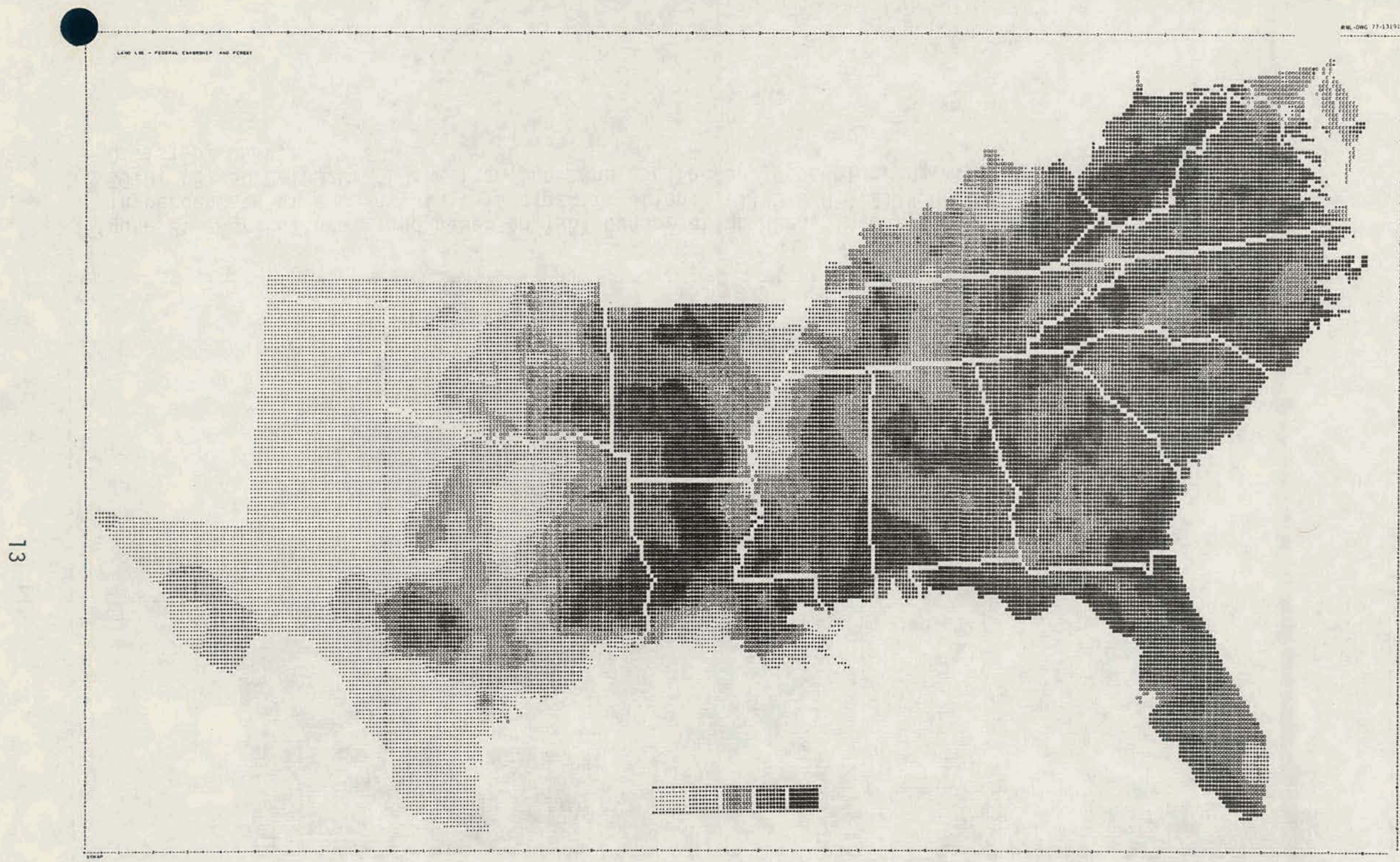

Figure 1. Forestland and federally owned land based on 1967 Conservation Needs Inventory. These land-use classes were combined, based on the assumption that much of the large federally owned lands in the Southeast are forested. Interval limits are expressed in percentage of a county in this classification (1) $0-10.0$, (2) 10.0-25.0, (3) 25.0-50.0, (4) 50.0-75.0, (5) 75.0-100.0. (Data from the Land Use Sector, Geoecology Data Base, Environmental Sciences Division, ORNL). 


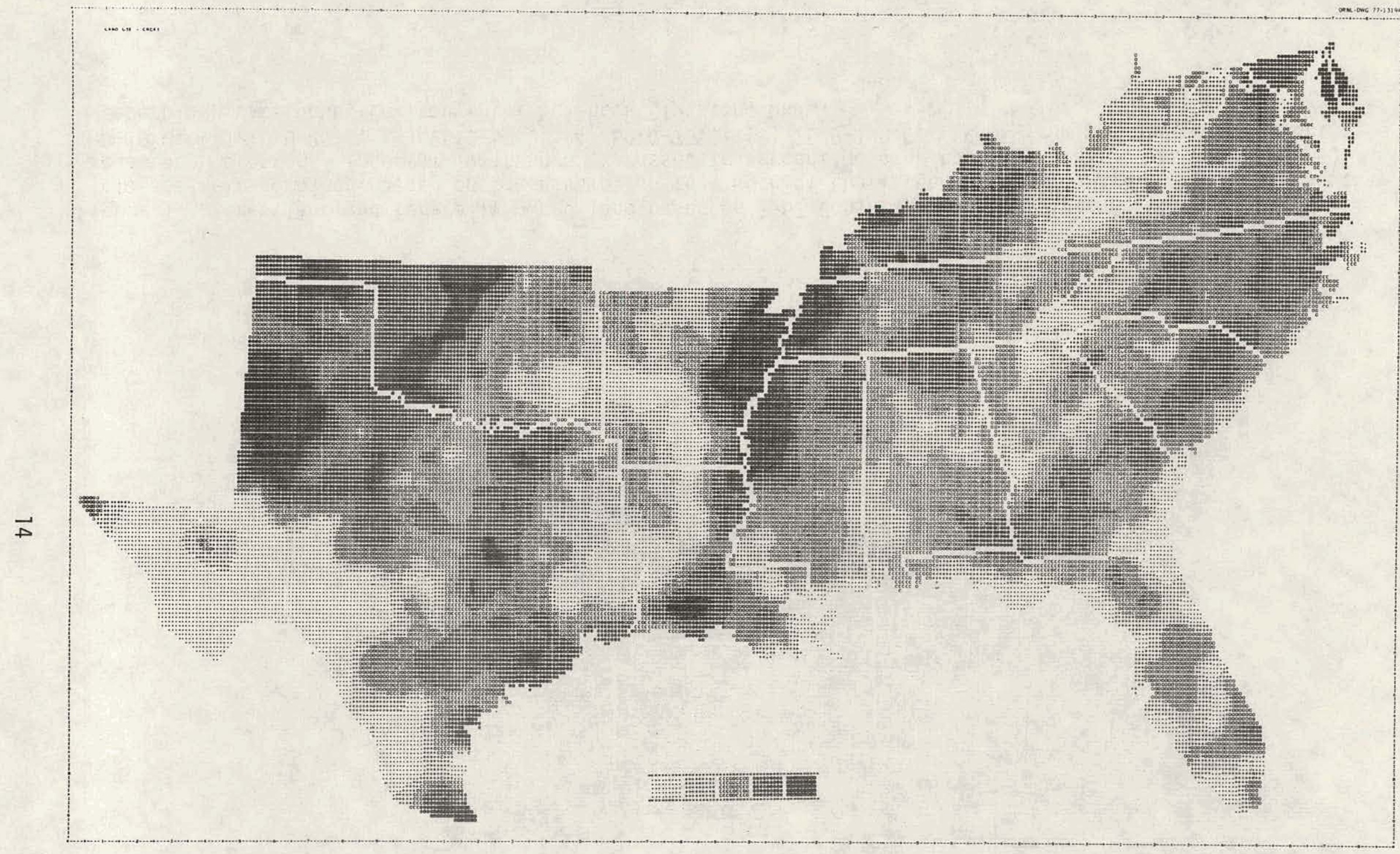

Figure 2. Agricultural land based on 1967 Conservation Needs Inventory. Interval 1 imits are expressed in percentage of a county in this classification: (1) $0-5.0$, (2) $5.0-10.0$, (3) $10.0-25.0$, (4) 25.0 50.0 , (5) 50.0-100.0. (Data from the Land Use Sector, Geoecology Data Base, Environmental Sciences Division, ORNL). 


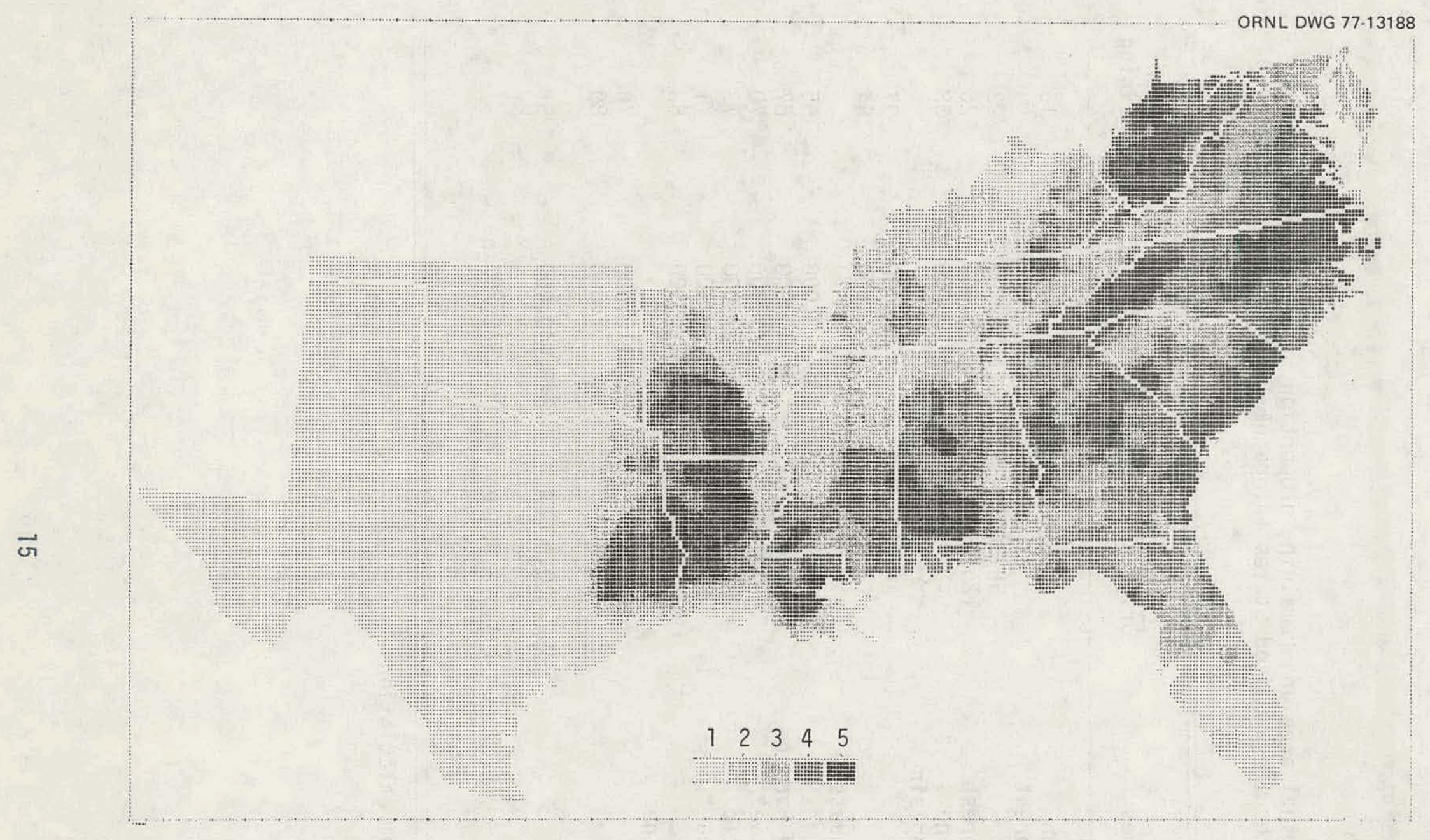

Figure 3. Forest, stand volume from U.S. Forest Service Forest Survey State Reports published between 1963 and 1.975. Growing-stock volumes are expressed as net volume of trees greater than 5.0 in dbh per total county area. Interval limits are expressed in cubic feet per acre as (1)<100, (2) 100-250, (3) $250-500$, (4) 500-750, (5) > 750. (Data from the Forestry Sector, Geoecology Data Base, Environmental Sciences Division, ORNL). 
Table 7. Original area and remaining proportion of vegetation types in southeastern United States (K1opatek 1979).

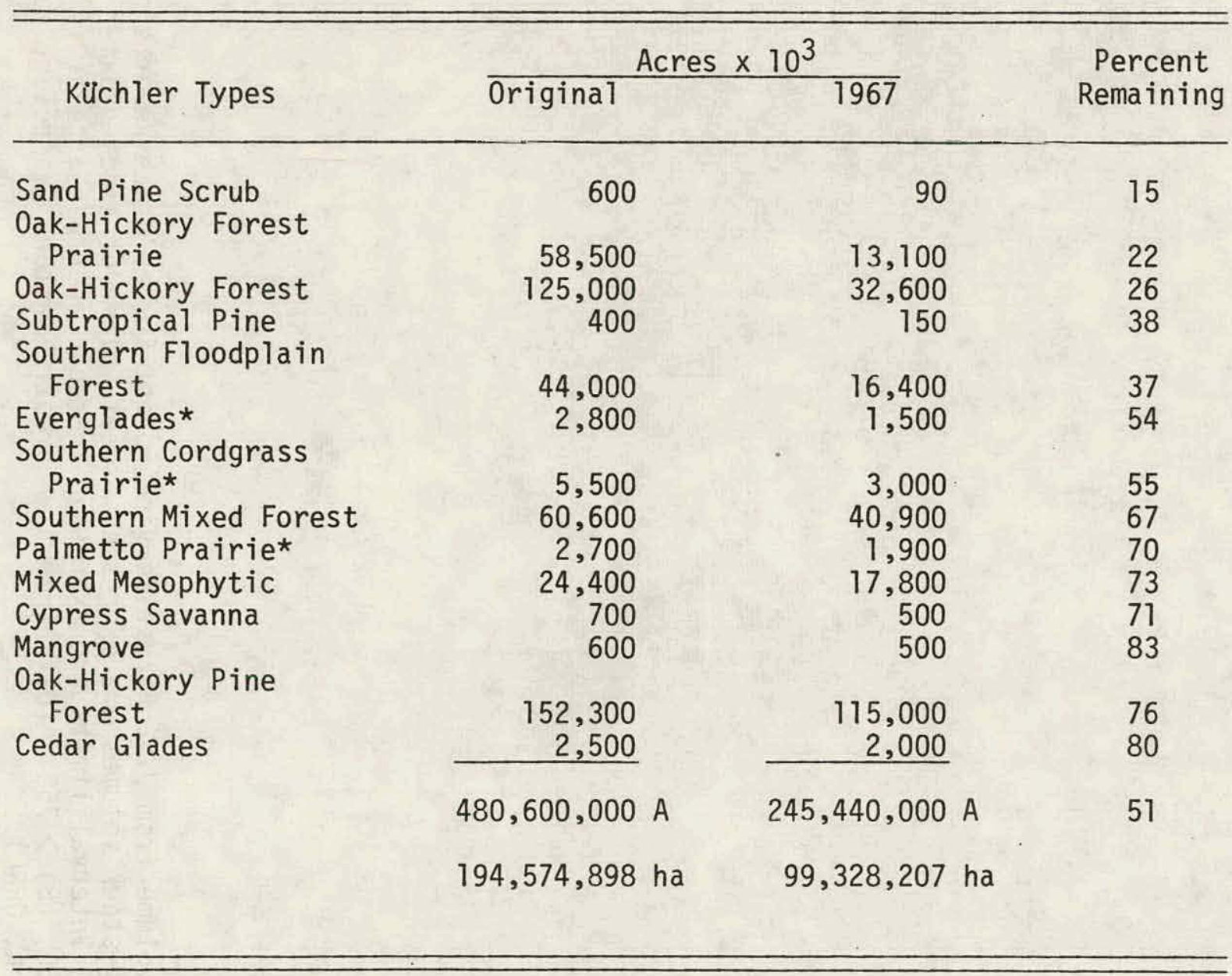

* Excluded from calculation. 
during settlement.

Loss of Carbon_from Litter_and Roots. Several studies have shown clearing would cause a prompt loss by oxidation, of $10 \mathrm{t} \mathrm{C} / \mathrm{ha}$ from below-ground pools. Wjth the previous assumptions of area, released carbon would be $1.09 \times 10^{9} \mathrm{t}$ or $0.0065 \mathrm{Gt} \mathrm{yr}^{-1}$. Assuming a root/shoot ratio of 0.25 (Rodin and Bazilevich 1967) and the previous assumptions of standing pool size and area, land clearing would result in carbon loss of $4.08 \times 10^{9} \mathrm{t}$ or $0.024 \mathrm{Gt} \mathrm{yr}^{-1}$.

\section{Carbon Gains to Soil and Above-ground Pools}

During the period of clearing, residual forests were accumulating biomass. Therefore, on the input side of a carbon balance, above- and below-ground biomass accumulations represent carbon sinks which must be estimated. This analysis takes a conservative position and discounts litter and soil organic matter accumulation.

Above-ground Accumulation. Land clearing and reforestation patterns are complex. PresumabTy land clearing dominated in the earlier to middle period of settlement, reforestation more recently. The calculation presented here is based on the midpoint between the original area and that estimated for 1967 (146 × $\left.10^{6} \mathrm{ha}\right)$. A standing pool for residual forests of $75 \mathrm{t} \mathrm{C} \mathrm{ha-1}$ and a conservative biomass accumulation rate of $1.6 \%$ of standing crpp per

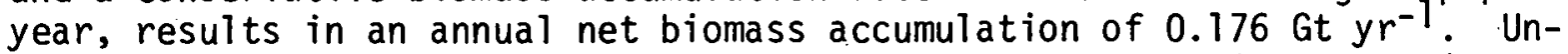
certainties include relative biomass accumulation rates which vary with stage of stand development and site quality factors. Also, the role of fire in reducing standing biomass is known only qualitatively.

Below-ground Accumulation. Assuming a root/shoot ratio of 0.25 , the estimated

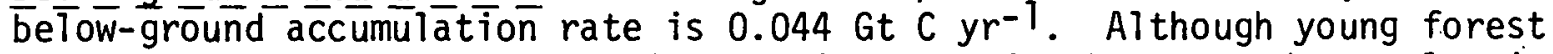
stands can have root/shoot ratios as high as 0.4 , these stands are low in total biomass and persist only for a short time.

Litter and Soil Organic Matter. Recovery of cut-over forests and reforestation wouTd cause carbon accumutation in litter and soil. A simple estimate is impossible to make, however. Litter and soil carbon pools respond over time to sustained changes in detritus input. At a regional scale, and for most specific sites, there are insufficient data with which to estimate accumulation rates. Simulation models based on underlying processes and empirical data should be used to estimate litter and soil carbon dynamics. Such models will help resolve simultaneous income and loss terms which may be greater than simple difference between terms.

\section{Carbon Balance}

Based on the approach just described, the southeastern U.S. was not a large source or sink for atmospheric $\mathrm{CO}_{2}$ during the period from 1800 to 1967 despite an annual clearing rate of $0.3 \%$ (Table 8 ). Historic trends 
Table 8. Estimated carbon gains and losses for the southeastern United States.

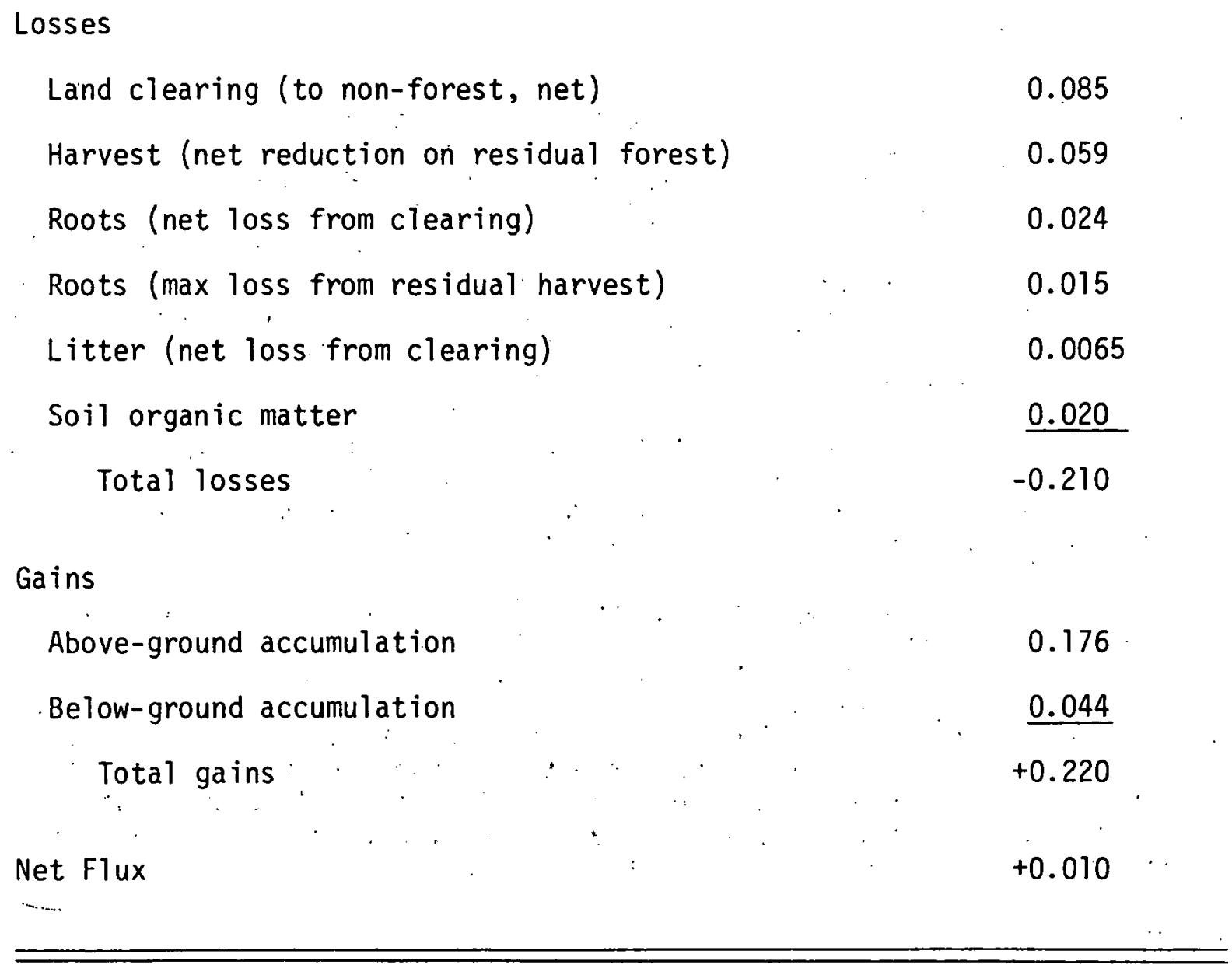


of the 20th century (old field succession, deliberate planting, and shift from erratic fires to control burns) may create net carbon storage in the third quarter of this century (Sharpe and Johnson, personal communication). But this regrowth means that growing. stock was lower, shortly before or after 1900. Therefore, annual depletion rate could have been greater than $0.3 \%$ per year for most of the 19th century. Underestimating pre-1800 clearing and fire could cause compensating errors. Essentially, this calculation was simplified to provide a framework for further revisions as information and insights become available.

A second approach to analyzing net carbon exchange in the southeast shows the range of uncertainties involved. If the original $200 \times 10^{6}$ ha of forest contained up to $3 \times 1010 \mathrm{t}$ of carbon, and if on the same area $0.75 \times 10^{10} \mathrm{t}$ remains, $2.25 \times 10^{10} \mathrm{t}$ have been lost. An additional $0.9 \times$ $1010 \mathrm{t}$ were harvested from residual stands. The tofal loss above-ground is then $3.15 \times 10^{10} \mathrm{t}$, with an additional $0.79 \times 10^{10} \mathrm{t}$ lost from roots, $0.33 \times 10^{10} \mathrm{t}$ from soil organic matter, and $0.11 \times 10^{10} \mathrm{t}$ from 1 itter. Durjing the 1800 to 1967 period there would have been a net loss of $4.38 \times$ $10^{10} \mathrm{t}$ of carbon or $0.26 \mathrm{Gt} \mathrm{yr}^{-1}$, equivalent to an annual increase of 0.12 ppm of $\mathrm{CO}_{2}$ in the atmosphere. Thus, the second approach suggests the region was a large source. If $50 \%$ of the net loss of carbon remained airborne, there would have been a net increment to the atmosphere of $10 \mathrm{ppm}$ if other regions of the biosphere were not acting as carbon sinks:

The foregoing analyses $i 17$ ustrate the components of net carbon balance for a broad region and the magnitude of carbon fluxes. While the parameters chosen are reasonable and based on extant data, it must be emphasized that changing the value of any assumption changes the net balance analysis.

The lesson here is simple. There are many uncertainties, and these will have to be resolved before making broad conclusions. These uncertainties are:

1. Areal extent of vegetation types - historic as well as present.

2. Estimates of standing carbon pools (wood, litter, soil, etc.) both initial and current conditions.

3. Weighted estimates of rates of carbon accumulation in wood, litter and soil.

4. Areal distribution and rates of forest cover disturbance and recovery.

5. Rates of prompt decay of detritus pools.

6. Turnover time of various forest products.

Another point illustrated by this analysis is the difficulty of drawing meaningful conclusions about the static or average condition. Just as an ecosystem is dynamic, so is a region. Analysis of the static condition or net change alone is inadequate. Simulation models of biomass transients 
of individual forests, and models of regional forest cover can be used to clarify dynamic patterns. In this way, the transient behavior of large forested regions can be explicitly treated.

\section{New England*}

Forest clearing in. New England began in the coastal regions and riverbottom lands before 1700 and continued at an increasing pace until about 1820. Abandonment of agricultural land began after 1820 as the center of agriculture moved west. Accompanying this trend was the reversion of lands back to forest. But recovery stands do not have as high a biomass as the old-growth. stands that are replaced for at least 100 to 200 years. At the same time, the net ecosystem production (carbon sequestering) of recovery forests is probably greater than that of old-growth stands at the time of initial clearing. Oniy where fire and other natural disturbances set old-growth stands back to an earlier stage of growth was there probably net ecosystem production.

Data are more reliable since about 1920 when information became available through the Journal of Forestry, and more so since 1948 when the U.S. Forest Service Inventory Data became available. The decline in forest area in New England continued until just before the beginning of the 20th century when a recovery period developed which lasted until recently (Table 9). In the last decade or so, the recovery period may have ended and further loss of forest area may be occurring (Woodwell et al. 1978).

The change in forest biomass over the last three centuries can be approximated by assuming that before 1820 a 17 the cleared stands were virgin and old-growth, and by taking growth data for principal species from current research. For the state of Maine, which has more forest biomass than all of the other New England states combined, clearing came late. Thus, forest biomass remain constant until well into the 19 th century. A major decline occurred around 1900, followed by partial recovery. In the other New England states; loss of biomass began earlier and continued until about 1900 when there was a recovery similar to that in Maine. For this reconstruction, biomass data for beech were taken from Hubbard Brook studies, oak data from Ovington (1962) and Monk et al. (1970) and pine/hemlock data from the JABOWA model (Botkin et al. $1 \overline{972}$ ). Biomass conversion factors were taken from dimension analyses of Whittaker and Woodwell (1969).

Biomass of the recovery stands has not attained that of the original forests before the arrival of European man (Table 9). The 1970 biomass for New England forests is estimated at about $2.4 \times 10^{9}$ tons of organic matter, an increase of $0.6 \times 10^{9}$ tons of organic matter since the minimum in 1890, but less than one-haif of the biomass of the forests in 1600 . At the same time, because young forests are more productive than old forests, the differences in net primary production are less dramatic. In 1970, net primary production is estimated to be $180 \times 10^{6}$ tons of organic matter per year, an increase of $24 \%$ since 1890 , and only $14 \% 1$ ess than the production rate in 1600 (Table 9).

\footnotetext{
*Based on an analysis by J. Melillo of the Marine Biological Laboratory.
} 
Table 9. Changes in forest area, biomass and net primary production in New England over the last four centuries. Based on a presentation by J. Melillo. Data from Wood and Botkin, 1979.

\begin{tabular}{lrrr}
\hline \multicolumn{1}{c}{ Attribute } & 1600 & 1890 & 1970 \\
\hline Area $\left(10^{6} \mathrm{ha}\right)$ & 16.0 & 9.5 & 13.5 \\
Biomass $\left(10^{9} \mathrm{mT}\right)$ & 4.9 & 1.8 & 2.4 \\
$\begin{array}{l}\text { Net Primary } \\
\text { Production }\left(10^{6} \mathrm{mT} \cdot \mathrm{yr}\right)\end{array}$ & 210.0 & 145.0 & 180.0 \\
\hline
\end{tabular}


By linking the JABOWA model with a decomposition model (Aber et al. 1978), the dynamics of carbon exchange of a forest can be simulated following a logging episode (Figure 4). In the first 15 to 20 years after a clear-cut, forest floor respiration will exceed net ecosystem production which is found primarily in young stems. During this period, the forest is a net carbon source. After 20 years, living biomass begins to increase more rapidly than respiration of dead biomass, and the forest becomes a net sink for carbon. Generally, the problem of changes in soil organic matter pools and soil carbon loss rates in forests subjected to different land use conversion rates has not been sufficiently studied, but may play an important role in determining carbon source/sink relationships of second-growth forests. Covington (reported in Bormann and Likens 1979) observed a decline in forest floor organic matter pools through the first 60 years following cutting of a northern hardwood stand at Hubbard Brook (Figure 5). After 60 years, the forest floor mass was about $95 \%$ of the pre-cut pool in an old-growth stand, the only sample of this class available. Loss of colloidal carbon to the groundwater is a possible flux of significance which is extremely difficult to measure, but should be examined closely.

With the uncertainties in estimating the carbon fluxes from the forest floor in successional stands, and in evaluating the flux of carbon from New England forests over the last three centuries, our tentative conclusion is that these forests have been acting as a small source over this period. The fiux to the atmosphere, from as far back at 1620, is equivalent to a total release of only $0.6 \mathrm{ppm}$ of $\mathrm{CO}_{2}$ to the atmosphere. Since 1950, the forests may have been functioning as a small sink, but further data on recent trends here are needed in order to further test this hypothes is.

\section{THE NORTH TEMPERATE ZONE FOREST CARBON POOL"}

In the United States and Canada together, the annual growth surplus of merchantable stems in 1976-1977 is equivalent to an annual net carbon storage of almost $93 \times 10^{6} \mathrm{~m}$ tons (Table 10). Only merchantable stem volumes in "commercial (U.S.) or "productive" (Canada) forest land are included. Comparing estimates of total standing timber for 1953 with estimates for the mid-1970's provides an approximation of total carbon accumulated in most of the forested area of the temperate zone (Table 11). Variation exists between countries in the criteria used to classify timberlands, but estimates for each country employ the same criteria for both surveys. The reliability of the data also vary, with greatest uncertainty in the data of east-central Europe and the U.S.S.R. For east-central Europe, the balance between growth and consumption of wood was assumed to parallel western Europe. Data for the U.S.S.R. must be considered less reliable than that of other countries because of the incomplete knowledge of the forests of central and northern Siberia -- the largest softwood area in the world. These limitations do not change the conclusion that nearly all the north temperate zone forest has accumulated carobn in commercial timberlands over the last three decades. The reports from China and South Korea imply

\footnotetext{
*Based on ana Tyses by T. V. Armentano and C. W. Ralston.
} 

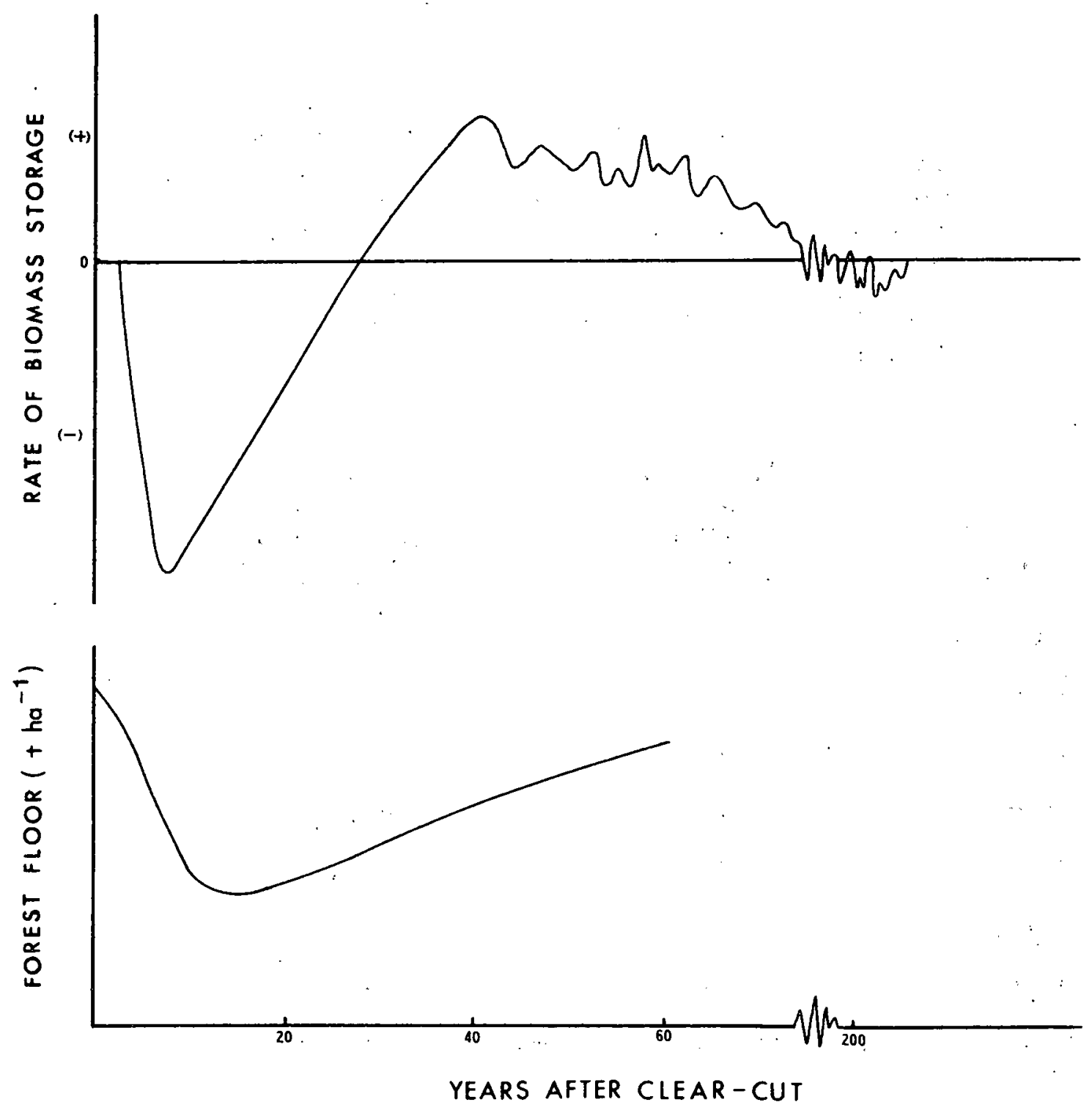

Figures 4 and 5 . Recovery of a forest from clear-cutting. Figure 4 (top): Schematic view of the increase in total biomass following clear-cutting of a northern hardwoods forest. Adapted from Bormann and Likens (1979.) Figure 5: Computer simulation of the response of forest floor biomass to clear-cutting. Adapted from Aber et al. (1979). 
Table 10. The carbon storage trends in U.S. and Canadian forests over the last 25 years based on the inventory data of the U.S. Forest Service (1978) and Reed.\& Associates (1978). Calculations assumed wood density was $0.6 \mathrm{~g} \mathrm{~cm}^{-3}$ on an air-dry basis, and carbon content was $50 \%$. The $12 \%$ mo isture content of the wood was assumed to be cancelled out by the bark weight. Based on an. analys is by C. W. Ralston.

\begin{tabular}{ccc}
\hline & Net Growth & Net Annual \\
Date of & Surplus & Carbon Storage \\
Inventory & $\left(10^{6} \mathrm{~m}^{3}\right)$ & $\left(10^{6} \mathrm{~m}\right.$ tons $)$
\end{tabular}

United States

1952

1962

1970

1976
61

132

158

211

99
18.3

39.6

47.4

63.3

Canada

1977 
Table 11. Estimated change in carbon pool. of timber lands in selected countries over the last three decades. The difference between the total standing timber was assumed to represent the storage of carbon. Based on analys is by $T$. V. Armentano and C. W. Ralston.

\begin{tabular}{|c|c|c|c|c|}
\hline Country & $\begin{array}{l}\text { Total S } \\
\text { Timber } \\
1950^{\prime} \mathrm{s}^{+}\end{array}$ & $\begin{array}{l}\text { anding } \\
0^{9} \mathrm{~m}^{3} \mathrm{j}^{0} \\
1970^{\prime} \mathrm{s}^{+F}\end{array}$ & $\begin{array}{l}\text { Net Change } \\
\left(10^{9} \text { tons C }\right)^{00}\end{array}$ & $\begin{array}{c}\text { Literature } \\
\text { Sources }\end{array}$ \\
\hline $\begin{array}{l}\text { Germany FR } \\
\text { Denmark } \\
\text { France } \\
\text { Italy } \\
\text { Finland }\end{array}$ & $\begin{array}{r}0.625 \\
.060 \\
.805 \\
.299 \\
1.491\end{array}$ & $\begin{array}{l}1.02 \\
0.045 \\
1.31 \\
0.35 \\
1.4-1.5\end{array}$ & $\begin{array}{c}+0.118 \\
-\quad .004 \\
+\quad .152 \\
+\quad .002 \\
-0-\end{array}$ & \multirow{3}{*}{ 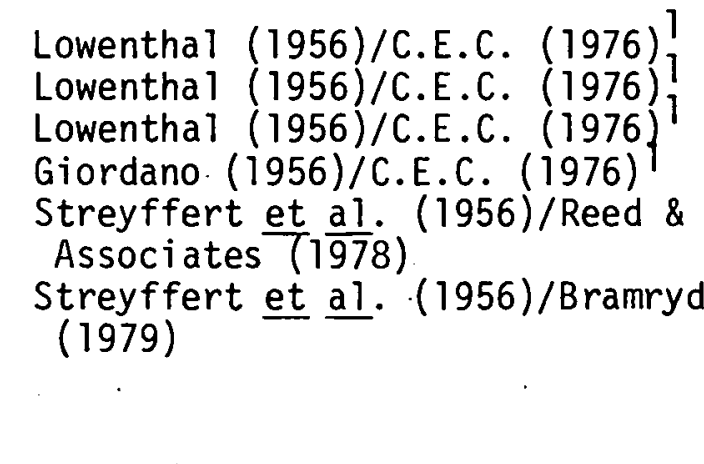 } \\
\hline \multirow{2}{*}{$\begin{array}{l}\text { Sweden } \\
\text { East-Central } \\
\text { Europe }^{\star}\end{array}$} & 1.820 & 2.36 & +.162 & \\
\hline & 2.86 & 4.55 & +.507 & \\
\hline U.S.S.R. & $\left(\begin{array}{l}58.7 \\
\text { (in 1951) }\end{array}\right.$ & $73-79$ & $+4.29-6.09$ & $\begin{array}{l}\text { Zon (1956)/Skoggstyrelsen in } \\
\text { Bramryd (1979)/Cliff (1973) }\end{array}$ \\
\hline Japan & $\begin{array}{l}1.90 \\
\text { (in } 1963)\end{array}$ & 2.09 & +0.57 & Ogawa (1965)/Forster (1978) \\
\hline $\begin{array}{l}\text { Canada } \\
\text { U.S.A.** }\end{array}$ & $\begin{array}{l}11.801 \\
13.28 \\
\text { (in 1945) }\end{array}$ & $\begin{array}{l}19.70 \\
22.70\end{array}$ & $\begin{array}{l}+2.37 \\
+2.83\end{array}$ & $\begin{array}{l}\text { Tunstell (1956)/Bowen (1978) } \\
\text { Josephson \& Hair }(1956) / U . S \text {. } \\
\text { Forest Service (1978) }\end{array}$ \\
\hline
\end{tabular}

$\begin{array}{lll}\text { Total } & \text { Merchantable stems only } & 11.00-12.80 \\ \text { (1953-1975) } & \text { Total trees } & 19.24-22.40\end{array}$

${ }^{+}$Usually 1953 except where noted ${ }^{++}$Usually $1973-1975 /{ }^{\circ}$ Includes bark, excludes stump $/{ }^{00}$ Assumes wood $=0.6 \mathrm{~g} \mathrm{~cm}^{-3}, 50 \% \mathrm{C}$.

*Calculated change in east-central Europe (Albania, Austria, Bulgaria, Czechslovakia, Hungary, Poland, Romania, Yugoslavia) assuming relative growth in standing stock the same as in west Europe as weighted for forest area/**Includes Alaska.

${ }^{1}$ Commission of the European Communities (1976). 
that the plantation forests there are also acting as a carbon sink but the magnitude cannot be estimated because forest survey reports are not available.

The total of 11.0 to $12.8 \times 10^{9}$ tons of carbon stored in the forests of the principal countries from about 1953 to 1975 implies a mean annual net absorption of about $0.5 \times 10^{9} \mathrm{~m}$ tons of carbon in merchantable stems of timberlands. This figure may underestimate the total net absorption of carbon by temperate zone forests because other forest components besides merchantable tree boles store carbon. These components include: a) stumps, crowns, and large roots of timber trees; b) non-commercial trees, shrubs; and c) soil organic matter. In addition, tree stands not classified as commercial because of small size, inaccessibility or reserved status may also be accumulating atmospheric carbon.

The contribution to the temperate forest carbon balance of the nonmerchantable components is difficult to assess because of great variation between and within stand types both in managed and natural forests. To estimate the importance of the non-merchantable carbon pool, merchantable stem yield in U.S. commercial forests was increased by $40 \%$ to account for stump, top, bark and branches (Spurr and Vaux 1976). Root production was accounted for by increasing the above-ground production total by $25 \%$ (Rodin and Bazilevitch 1967). These adjustments increase the estimated net addition of carbon to commercial forests of the temperate zone to approximately 19.2 to $22.4 \times 10^{9}$ tons. of carbon over 22 years, or 0.87 to $1.02 \times 10^{9}$ tons per year (Table 11).

Accounting for carbon exchange in uninventoried forests is difficult because of lack of data and because definitions of stands included in forest inventories vary between countries. In the U.S. about $34 \%$, and in Canada about $26 \%$ of 1 and classified as forest is not included in the national forest inventories, but this includes much open woodland and shrubland. In Europe a smaller percentage of forest is excluded from timber surveys. The forest areas summarized in Table 11 total $1.3 \times 10^{9}$ ha of a total of $2.4 \times 10^{9}$ ha of total forest area in the temperate zone (Whittaker and Likens 1975). Generally, most of the productive stands are inventoried except for reserved stands. which are relatively small in area. Together with presumed net growth in China, Korea, and in other countries of Europe and Asia and in the south temperate zone, which have not been considered here, the carbon sink from uninventoried stands of the temperate zone may reach 1.0 to $1.2 \times 10^{9}$ tons per year.

Thus, temperate zone forests may be absorbing carbon equal to nearly $50 \%$ of the approximately $2.3 \times 10^{9}$ tons added to the atmosphere each year (Woodwell 1978).

\section{Policy Aspects of a Temperate Zone Forest Research Program*}

Two principal policy questions concern the relationship between forest growth and consumption and national energy needs. The first is whether temperate zone forests can be managed for absorption of significant quantities

*This section was prepared by J. Hett. 
of carbon released to the atmosphere without diminishing other benefits of forests. The forests most active in producing wood and in fixing $\mathrm{CO}_{2}$ are young, vigorous stands growing on productive sites (Figure 6). If wood removal can be managed such that an optimum proportion of immature forests remain in the growth stage characterized by high net ecosystem production (NEP), then both wood production and carbon fixation will be optimized. Under these conditions, the principal remaining questions are: Is the total carbon tied up in wood large enough to reduce the rise of $\mathrm{CO}_{2}$ in the atmosphere? Are there management strategies which can increase total NEP (carbon sequestering) at an acceptable cost (e.g., improving stocking in the understocked southeastern forests)?

The second policy question is whether forests can supply enough energy to reduce significantly our dependency on other fuels. Bethel et al. (1979) estimate that the total biomass inventory in the U.S. is gaining $0.30 \times 10^{9}$ oven-dry tons or $4.8 \times 10^{12}$ Btu's (quads) each year. They also estimate that the forest industry is currently using 1.24 quads of wood-derived energy, while households use 0.20 quads of wood energy for fuel and 0.15 for charcoal. The total of 1.59 quads is much less than the 4.8 believed to be available from today's forests. These authors also suggest that, with intensive management (fertilization and use of wood removed in thinnings), the total annual harvest from American forests could be raised to 7 quads or $12 \%$ of present total U.S. energy use. The increasing energy needed for fertilizer production, however, would reduce the net energy yield from forests.

These statistics suggest that forests can play a larger role in meeting U.S. energy needs. What fraction of the wood sequestered as NEP will be kept in storage and what should be used as fuel are questions whose answers require economic and political considerations not dealt with in this workshop. The ecological implications of managing forests as $\mathrm{CO}_{2}$ sinks must also be studied, particularly questions of the nutrient losses accompanying wholetree utilization and shorter rotation times. Nutrient losses during logging may change aquatic ecosystems and reduce the productive capacity of the managed forests. A detailed analysis will be required to determine whether the energy needed to replace these nutrients would allow their removal in the first place.

\section{DATA NEEDS AND RESEARCH RECOMMENDATIONS}

\section{Limitations to the Analys is of Temperate Forest Carbon Exchange*}

The analysis already presented for data on commercial timberlands suggests the temperate zone forests may be acting as a net carbon sink equivalent to nearly one-half the annual rise of carbon in the atmosphere. The uncertainties of this estimate suggest a margin of error equal to $25 \%$ to $50 \%$ of the mean, or more. Thus, Bolin's conclusion (1977) that temperate zone forests are nearly in balance with the atmosphere with respect to carbon exchange today cannot be rejected.' Conversely, the uncertainty does not rule out the possibility that temperate zone forests are withdrawing carbon at a greater rate than suggested. by Armentano and Ralston (see previous

*This section was prepared by $J$. Hett and other workshop participants. 


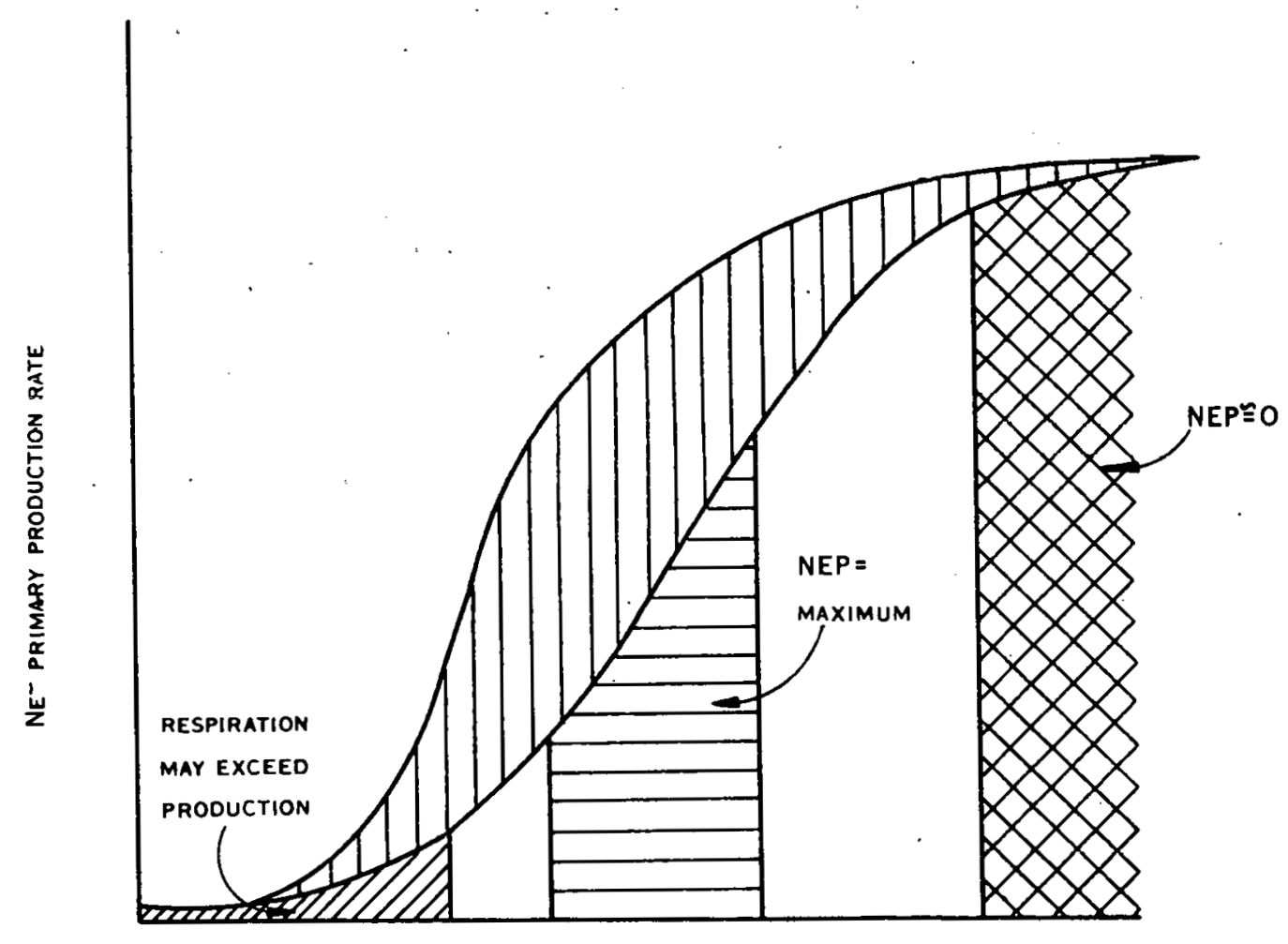

ABOVE-GROUND BIOMASS OR TIME FOR FOREST GROWTH

Figure 6. A graphic model of the hypothetical relationship between net primary production, above-ground biomass and net ecosystem production (NEP) for a forest. The differences between the two curves (vertical bars) represent increase in production that can be attained by improving stocking, fertilization or selecting productive species. Net ecosystem production is maximum during the rapidly growing intermediate phase but can drop to zero in an old-growth stand. In many forests, however, natural or anthropogenic disturbance may set the forest back to an earlier stage, followed by partial or complete biomass recovery. If disturbances are frequent or destructive, the recovery curve could be shifted downward. The actual values along the axes vary with forest type and site conditions. 
section) considering the incomplete understanding of:present forest growth trends in much of. Asia, eastern Europe, and in the taiga. Before recommending research goals to reduce data uncertainties, the source of inadequacies in the data base should be defined. The workshop participants identified the following areas of data limitation as obstacles to a better understanding of the role of temperate zone forests in the global carbon cycle.

Heterotrophic Loss Rates and Soil Carbon Pool Changes Over Time

Whether forest ecosystems are sources or sinks for carbon depends upon an evaluation of net ecosystem production (NEP) or long-term retention. In forests, wood and soil carbon are the principal components of NEP. Over periods of centuries, soil carbon forms the major carbon sink of forests. Deep humus can ti.e up carbon for thousands of years (Schlesinger 1977), compared to wood; turnover times for wood are generally from a hundred to a few hundred years. However, neither the size of the stable stock of soil carbon, nor loss and recovery rates of soil carbon following interventions such as land use conversions are well known for most of the world's temperate forest regions.

In many forests the mass of carbon in litter and soil is approximately equal to that in vegetation, while in boreal forests, the carbon mass in litter and soil is double that in vegetation (Schlesinger 1977, personal communication 1979). These estimates are based on relatively few studies and on data with a high variance. The coefficient of variation (CV) for , pool size estimates of temperate forest litter and soil carbon is 35\%, while the CV for boreal forests is $53 \%$ (Schlesinger 1977). Thus, while additional information on soil carbon pool sizes is needed for most forest types, the boreal ecosystems should be a first priority.

Even when surface litter and soil carbon pools are estimates, however, the carbon stored in woody litter often is not considered. This fraction may be relatively large (Cromack 1973, Grier and Logan 1977, W. Reiners, personal communication). For example, down-logs contributed $20 \%$ of the total ecosystem biomass in a Pacific silver fir (Abies amabilis) stand in Washington (C. C. Grier, personal communication). Pacific coastal forests carry at least 50 to 75 tons ha-f of coarse woody debris through all successional stages, with old-growth stands containing larger amounts. (J. Franklin, personal communication 1979). New data are needed on total woody litter masses, including standing dead material, surface deposits and buried wood. Data also are needed on the turnover times for each of these pools.

A critical aspect in evaluation long-term retention of $C$ is the oxidation rate of soil organic carbon. Preliminary evidence suggests that alterations such as forest harvesting or land use conversion bring about changes in oxidation rates, but the direction and magnitude of these shifts may vary widely in temperate and boreal forests. Losses of colloidal carbon into water bodies, followed by transport to downstream ecosystems, also may be important, but has been seldom studied. Data on changes in soil carbon mass over time following disturbance are urgently needed for the major types of forest land alterations. 
The presently available conversion factors used to estimate total carbon from forest soil organic matter measurements also are subject to question. Schlesinger (1977) has pointed out the lack of soil bulk density estimates in the presently available literature. Schlesinger also critized the general use of 0.58 as a conversion factor for estimating $C$ from soil organic matter. He recommended a conversion factor of 0.53 for surface soils and 0.40 for subsoil.

\section{The Storage Period of Forest Products}

Early in human history, man discovered how to use wood for structural purposes. Other uses have evolved over the centuries, making wood a very prominent material in the civilized world. Its use in many forms has led to the large harvests already mentioned, but also to long-term retention of wood products in buildings, libraries, and deep solid-waste deposits.

Recent reviews of the world carbon cycle usually treat removal of forest trees and conversion to wood products as an immediate source of atmospheric carbon. There is, in fact, a great array of wood products with a wide range in storage half-life. The half-life may be very short in the case of newsprint, or very long in preserved material such as railroad ties or building structures. Large quantities of wood harvested from the original U.S. forests may be still in structural storage, and much of current forest harvest also may be going into storage.

Little information exists on the quantity of carbon presently in stored materials or the fluxes related to this pool. For instance, there is no quantitative estimate of the storage half-life of current harvests of wood products in the United States, although data are available on the general use made of timber removed from forests of most nations. A few estimates of the quantities of forest products stored in landfills and incinerated by municipalities are available, but these are not enough data to provide more than a crude estimate of the final disposal of wood products.

Information on the storage half-life of all woody material converted into either pulp and paper or structural uses, including railroad ties and mine props, should be obtained. Data are needed for the past 25 to 50 years, the present, and a projection over the next several decades as to the expected retention of forest products from tropical as well as temperate forest countries.

\section{Forest/Non-forest Conversion Rates}

The rates of change from forest to non-forest area directly affect carbon pool sizes and carbon flux rates. A total of $4.52 \times 10^{6}$ ha of commercial forest have been converted to other uses in the U.S. over the past 25 years (U.S.D.A. 1978). Most of the loss has been from federal lands $\left(3.5 \times 10^{6} \mathrm{ha}\right)$, while private industry lost $1.5 \times 10^{6}$ ha. State and local governmepts, the only land owners to ga in commercial forest land, added $0.9 \times 10^{6} \mathrm{ha}$. These data are representative of those available, but are of limited value for carbon budgets because changes in commercial forest area 
may not result from change in land use, but from change in land status. For example, much of the area lost by the U.S. government resulted from land transfers from the Forest Service to the National Park Service, or from reclassification as wilderness. Data are needed which describe actual changes in forest area over a time sequence long enough to permit assessment of net change in carbon storage for specific areas.

In the eastern U.S., large segments of the landscape have returned to forest following abandonment of agricultural land. For example, in New England, $16 \times 10^{6}$ ha were forested in 1600 , but by 1890 , the forested area had decreased to $9.5 \times 10^{6}$ ha (Table 9). By $1970,13.5 \times 10^{6}$ ha of forest remained. Similar changes occurred in the southeast where massive development of cotton in the 19th century was followed by widespread reversion to secondary forest in the 20th century. Other changes in land use patterns took place in other regions. Detailed documentation of the kind available for eastern Tennessee, where land use changes for five counties were examined over the period from 1939 to the early 1960's (Hett 1971) are needed for New England, the southeast, and other partially forested regions of the U.S., Canada and Europe.

The two world wars caused extensive forest devastation in Europe, setting back improvements in forest management that began in the 19th century. The cumulative losses due to the war may have been offset by the regrowth of forests in North America, but a comparative study of forest trends in the two continents cannot be made now because of fundamental differences in the available data. A review of all published data might permit better delineation of this issue, but the major limitation is simply the inaccessibility of forestry statistics from the various countries.

Natural changes in forest area also are important. For example, in much of the boreal forest, the natural successional pattern is from forest to muskeg or peat bog by a process called "paludification". Often these changes are irreversible, but we know little about either the direction or magnitude of the rates of change. Much of the literature and statistics for Canada and elsewhere apparently lump the forest and peatland mosaic together as one forest type. Also, data are not now available on how these two ecosystems differ in storage of carbon and/or carbon turnover rates.

Coordination of a literature survey with Canadian and European scientists should precede development of any new field research programs. Despite extensive studies in the U.S.S.R., a major inadequacy exists in western knowledge of paludification of peatlands, an area that would require field measurements before any improvement can be made in the order-of-magnitude estimates of the importance of this boreal forest process on the global carbon budget.

\section{Adequacy and Reliability of Biomass Conversion Factors}

The first step in developing a temperate zone forest carbon budget is analysis of the available data on biomass components. In the U.S., this step involves use of conversion factors to translate the Continuous Forest Inventory data (from the U.S. Forest Service) into carbon flux information. These data, 
and similar data from FAO for Europe and Asia have measurements only on bole wood amounts.

For crowns, stumps, tops and bark, Spurr and Vaux (1976) have suggested multiplying bole weight by 0.40 and adding this to the bole wood estimate. Available data suggest that the 0.40 conversion factor may not apply to all forest types. Ovington (1962) observed a root/shoot ratio in the range of 0.20 to 0.30 in many forest trees. However, in the Brookhaven oak pine forest, the root/shoot ratio was 0.52 (Whittaker and Woodwell 1969). This high value apparently is a result of massive root systems which have survived fires and are now supporting relatively young and small shoots. Ratios of below-ground biomass (including stumps) to above-ground biomass (including branches and foliage) on the Walker Branch Watershed at 0ak Ridge were $0.19,0.27,0.24$, and 0.31 for pine, oak hickory, chestnut oak and yellow poplar stands respectively (Harris et al. 1973). Root (including stumps)/ shoot (bole only) ratios for these forest stands average 0.35 , with a range from 0.32 to 0.39 . Root/shoot ratios in the Pacific Northwest Douglas-fir Region ranged from 0.14 to 0.22 with most approximating 0.20 (Edmonds 1974; Grier et a 1. 1974; Grier and Logan 1977; Grier, personal communication). These studies included forested ecosystems of all ages, and both coniferous and deciduous forest types.

Crown/bole relationships appear to be even more variable than root/shoot ratios. For the above forests at Oak Ridge, crown (branch and foliage)/ bole ratios average 0.33 with a range of 0.29 to 0.35 (Harris et al. 1973). Subalpine spruce-fir forests in Colorado have a crown/bole ratio of 0.40 (Landis and Mogren 1975), while subalpine species in southern B.C. have ratios of 0.16 and 0.19 for mountain hemlock (Tsuga mertensiana) and Pacific silver fir (Abies amabilis) respectively (Krumlik 1974). Lower elevation ecosystems in the Pacific Northwest vary from 0.07 for an old-growth Douglasfir stand in Oregon (Grier and Logan 1977) to 0.61 for a young alder stand in Alaska (Van Cleve et al. 1971). Long (1976) reports that western hemlock (Tsuga heterophylla) ratios increase from 0.34 to 0.60 with stand development, while Douglas-fir (Pseudotsuga menziesii) in the same stands decreased from 0.19 to p.08. It is apparent that for crown/bole ratios (1) there are significant differences in species proportions and (2) the ratio changes as a forest stand develops.

Forest understory plants also contribute to carbon dynamics and often must be estimated indirectly. These include herbaceous materials, woody shrubs, understory trees and tree saplings less than $12.5 \mathrm{~cm}$ dbh. In some forests, these components may equal or exceed the total biomass in tree boles; in others they may be almost non-existent. On the average, they probably represent on the order of $10 \%$ of the growing stock. Although the role of understory components in forest development should be better known, especially for shrub-dominated stands, this need is not a first-order one.

Development of biomass conversion factors and estimates of regional pool sizes must account for variation in site productivity. Early forest clearing concentrated on the most productive forests, leaving behind lower quality stands. Many of the latter persist, although some were cut later. 
Large parts of the southeastern U.S. west to Okalahoma and Texas are classified as belonging to site class five by the U.S. Forest Service. These forests will ordinarily be characterized by lower biomass and growth rate than more productive stands. They would release less carbon when cleared, but would also fix less carbon in recovering from tree removal. Applying conversion factors from stands of higher site quality would inflate the role of lower quality forests in carbon exchange.

\section{Problems of Aggregating Carbon Pool Estimates from Different Data Sources}

The Continuous Forestry Inventory of the U.S. Forest Service probably can be used, with some reservations, for the gross areal estimates of net carbon exchange within the U.S. The USFS classification system of about 100 forest types could be used as a first level of aggregation for forest carbon pools. However, since Canada and overseas nations in the temperate zone use different classification systems, production data from these locations could not be aggregated with the U.S. forest types without knowing the ecological and statistical implications.

Private and other non-commercial forests often are not managed under USFS guidelines. Thus, the CFI may not reflect the different growth and removal in these lands. A separate inventory, perhaps principally a literature compilation, may be necessary. The U.S. forest classification system also presents difficulties for analysis of more widespread or "higher order" forest types such as oak-hickory forest in the U.S. which can be subdivided into several variants, and for non-commercial types. Both in North America and abroad the applicable allometric equations and biomass conversion factors are missing for many of the individual forest types. Certain forest types in the U.S., Sweden and West Germany are exceptions to this deficiency, but application of these multipliers beyond the stand types for which they were developed is uncertain.

Extrapolating estimates to other forest types can be recommended only if the extrapolation can be shown to be valid. For many forest types that have not received close study, the reliability of extrapolation is uncertain. Without knowing the validity of the extrapolation, the accuracy of the pool estimate at each level of aggregation is unknown. A compromise in computational procedures is needed between the mounting of a large program of new data acquisition, and the application of existing allometric equations indiscriminantly. For minor forest types, the problem can be approached by giving a range in biomass estimates which reflects expected error from applying allometric equations or conversion factors from better known systems. If the expected error is acceptably small, the gathering new data for these types of forests would not be warranted.

An alternate approach to aggregating at the forest type level is to work almost entirely at a still higher level of biotic aggregation, e.g., the biome or "ecoregian" level. Appendix II shows that CFI data can be recast as biome level data, although there may be an increase in statistical uncertainty. Higher-level aggregation generally brings with it difficult questions as to inclusion or exclusion of pockets or edge areas of atypical ecosystem 
types, and the pooling within the biome of forest types that may be quite different in carbon cycling characteristics. Thus, accuracy of the estimates may be reduced systematically but unintentionally. The advantages of a higher level of aggregation is the implied lower requirement for data from specific forest types. Other work has shown, however, that even for relatively small geographic areas, forests may vary greatly in productivity and biomass and significant variations occur as a function of stand age and stocking class (Sharp et al. 1975; Sharpe 1975). Furthermore, many published studies report work from carefully selected stands which are not representative of the region's vegetation either in productivity or age structure.

Thus, given the limitations of higher levels of aggregation, most workshop participants agreed that greater flexibility in summarization and statistical interpretation would be obtained by starting with the lowest practical level of aggregation. They recognized that, in some countries and for some forest types, wide-area averaging would be necessary, but careful review of the literature would identify forest types for which averaging would be unacceptable. In some areas, such as in the southeastern U.S., where Oak Ridge National Laboratory has been assembling a county-level base of forest resource information, data may be available at levels below the forest type.

\section{Recommendations for Research}

The magnitude of apparent past carbon releases from temperate forests, and the possible rate of $C$ retention in these systems today, make imperative the need to remove uncertainties described in the previous sections. The goals set for the workshop concerned primarily evaluation of research needs if warranted by the magnitude of carbon dynamics in the temperate forest pool. The evidence available is sufficient to conclude the temperate forest exchanges are large; thus, the following sections address the research planning and data synthesis needs of temperate forest carbon problems.

\section{Research on Soil Carbon Pool Sizes}

(a) Data on temperate zone soil organic carbon (including woody detritus) is available for only a few forest types, mainly those left undisturbed because they were too poor for agriculture. Site quality, disturbance patterns and stand age also may determine the soil organic pool and its release of carbon to the biosphere following human manipulations. Documentation of exchanges of carbon between the soil and the atmosphere during recovery of a stand after disturbance is especially needed. Review and analys is of presently available information is needed for:

- magnitude of the soil organic pool (including woody detritus) for forest types that have not been studied adequately; the loss of carbon from clear cutting, from various logging rotations, as well as from the effects of agricultural conversion, forest fires and insect or disease outbreaks; and the inhibitory effects of atmospheric pollutants on soil and plant processes controlling carbon cycling. 
(b) Remeasurement of soil carbon content at sites measured 20 or more years ago would help to document turnover times and recovery transients for a relatively large pool, at a modest cost. Remeasurement activities could be completed over a one to two-year period, and results could be made available as input to modeling assessments within three years.

(c) Special problems in the analysis of soil carbon exist in the boreal forest where turnover rates are generally low and the organic carbon pools are large. The data base on woody detritus, forest litter, surface soils, and deep soil horizons is sparse for all the northern coniferous forest types, but weakest for the peatland areas.

(d) Increased understanding of the ecosystems making up the boreal forest is needed. An analysis of the current literature and new field studies should be undertaken to define the differences among these systems. A first step would be to obtain data available from Canadian, Russian and Scandinavian studies, preferably through direct contacts with some of the principal European scientists. Another source of information is the recently completed soil inventory of Canada, which for some provinces is available on computer.

Determine the Storage Life of Forest Products

The long-term fate of harvested forest products throughout the temperate zone is uncertain. The half-life of pulp, paper, container and construction products must be determined by analysis of information from the forest products industry, lumber and construction industry, railroad and mining materials, and waste management operations. It may be necessary to make an inventory of existing wood products in landfills and the retention of buildings in urban areas of various ages. Some of the needed information is readily available and programs are underway to make more of it accessible. Because the data are from sources not familiar to ecologists, a coordinating group with representatives from forest products and waste disposal industries and regulators should be assembled to provide guidance on the use of existing information.

Estimation of Forest Areas and Land Conversion Rates

(a) Part of the difficulty in determining the effect of changes in forest area on the carbon balance arises from differences in forest classification systems. Several forest classification systems exist, but no single system summarizes the vegetation of the temperate zone so as to allow aggregation of data from different countries. A forest classification permitting aggregation of forest stand data might utilize compatible elements of existing systems. Occasionally, forest types from different schemes are interchangeable, but in other cases, inconsistencies between classifications mean that combining elements from two or more schemes would omit areas of some types, or produce a tendency to count other types twice. Types such as old fields or peatlands, and certain transitional forest types, may not be accounted for in classification schemes even though they are significant in the temperate zone carbon budget. Resolving these problems will require that the details and shortcomings in existing systems be examined carefully by researchers in a workshop attended by forest classification experts and specialists in forest and soil 
carbon studies. The goal should be to devise a system that is suitable for carbon pool anaiysis.

(b) Assessment of conversion rates from one forest type to another is complicated by differences between countries in methods of collecting, analyzing and reporting data. Specialists in assessment of land conversion processes from temperate zone countries should try to reconcile these data inconsistencies and agree on interpretation of the results.

(c) The potential for determining areas of forest in countries such as China and the Soviet Union through satellite imagery, must be explored systematically. For recent areas of change in North America and western Europe, information is available in the form of aerial photographs and large-scale mapping. Supplementary ground verification and new photography might be needed in specific areas. Existing data may eliminate the necessity for a major program of new data acquisition. Particular attention should be given to locations where land conversion is occurring rapidly.

Research on Biomass Conversion Factors

(a) An intensive 1 iterature review of the biomass and carbon content of above- and below-ground tree components from throughout the temperate zone should be made in order to determine the extent of further research needs. Special efforts should be made to work with foreign and American scientists, particularly those who might be in a position to obtain this information easily from field programs already underway. The review should proceed as much as possible on a forest-type basis and include both commercial and. non-commercial forest lands of different stand ages and stocking densities.

(b) A similar literature search should address the question of how much additional biomass is present in the understory and how it changes with time (most young forest stands have less understory than old-growth stands). Also, an important step in data accumulation is estinating understory biomass for mature forests of each major biome type. Many of these data should be available from the studies carried out during the International Biological program. Special attention should be paid to relationships between understory biomass, tree biomass increment, and growing stock volume, particularly in regrowth stands.

(c) Where literature analysis of biomass relationships reveals major data inadequacies, a supplementary field program of data acquisition should be undertaken. Data inadequacies are to be expected in certain forests, such as regrowth stands in the northeast U.S., or shrub-dominated woodlands in the Lakes States or southern Rockies. Probably the best approach to obtaining data for these stands would involve a cooperative program with local academic institutions or field stations.

Synthesis and Interpretation of Program Results for Policy Analysis

Results from current research on biospheric carbon pools, and human influences on them, need to be examined from the viewpoint of managers in 
the renewable energy and materials sector and the implications of their decisions for the carbon cycle. A comprehensive biospheric assessment should provide for analysis of policy alternatives among scientists, resource managers and industry. The major questions to be addressed include the following:

- Cost and feasibility of managing temperate forests as carbon sinks;

- The effect of increased forest residue utilization on carbon release from soils and on forest growth potential;

- The significance for the forest carbon pool of the development of forests for fuel sources;

- The implications from expansion of tree farming, short-term rotations and increased use of fertilizer on the role of forests as carbon sinks; and

- The impact of changing national energy policies on forests, especially the emissions from increased dependence on coal and oil shale.

Broader policy issues involve the influence of the forest products market economy, foreign trade in wood and paper products, as well as possible increasing dependence on forests for raw materials if the availability of fossil-energy based materials becomes constricted. All of these questions require collaboration of the biological research community with policy analysts and technical staff from federal agencies and industry.

\section{WORKSHOP CONCLUSIONS}

The forest inventory data reviewed here suggests the temperate zone forests could have functioned for the past several decades as a net sink for $10^{9}$ tons of carbon annually. This is nearly one-half of the total annual rise in carbon concentration of the atmosphere.

However, due to the limited data on non-commercial timberlands, nonmerchantable tree components, and soil organic matter changes, the precision of this estimate of temperate zone $C$ retention may be only within one-quarter to one-half of the true value. Despite this limitation, the available data suggests strongly that temperate zone forests probably are not a source of carbon as implied by the $2.2 \times 10^{9}$ tons annual release postulated by Woodwell et al. (1978).

The principal areas for which new information would reduce uncertainties in estimates of carbon uptake and losses from temperate zone forests include:

1. Improved estimates of detrital carbon (forest floor and organic content of soil) in stands of different forest types and ages, particularly those subject to fire control and periodic clearing.

2. Improved estimates of $C$ in relation to rates of paludification, wildfires, and storage of detritus in high-latitude peatlands, particularly those of the boreal forest in Schlesinger (1977). 
3. The growth rates and biomass of forests in temperate Asia (except Japan), Siberia and Eastern Europe are undergoing change, and should be re-evaluated.

4. The storage half-life of forest products, and the proportion of wood persisting in buildings and waste disposal sites, must be known much more precisely.

5. Current conversion rates from forest to non-forest and the resulting carbon pool gains and losses should be determined for all temperate regions. The need is greatest wherever afforestation has been extensive (Western Europe, Asia) and where clearing and reversion to forest have been occurring simultaneousiy (e.g., United States).

6. The growth trends of non-merchantable components of commercial timberlands is poorly known. The biomass of roots, stumps and tops should be determined for a wide variety of forest types and ages.

Research initiatives are recommended to increase the resolution of these problem areas within three years. For certain of these needs, an intensive literature assessment by forest research leaders from the temperate zone nations would reduce uncertainties about specific topics. In other areas, additional data are needed.

Two questions of a policy nature having major ecological implications were discussed. One examined whether temperate zone forests can be managed as a carbon sink, and what silvicultural methods or nutrient additions would be needed to divert more carbon into long-term wood storage. Another asked whether a portion of wood production could serve as a fuel source, thereby reducing reliance on fossil fuels. The answers to both questions are cautiously affirmative, within the limits of data available. Although the answers can be given with reasonable confidence for certain well-studied forest types, existing data do not provide a reliable assessment in most forests.

The assessment of the results from temperate forest carbon pools, as well as other biosphere components, will be aided greatly by a simple, mass-balance modeling program (such as used in this report), in conjunction with the individual studies of carbon exchanges and the assessment of overall significance. The dynamics of the carbon cycle may be understood best through a combination of large-scale simulation-model studies, and mass-balance models which follow the dynamics of carbon pools, both large and small, over extended periods. For each model compartment, or sub-model, data needs can be evaluated and results of individual research projects reviewed as an ongoing or cumulative process; with a focus on long-term relationships. Newly available data should be re-evaluated quickly, and incorporated into program planning. The ongoing assessment of results on the temperate forest, as well as on other large biospheric carbon pools, is needed to assure that all studies capitalize on available data, on research in other countries, and on emerging insights as research progresses. 


\section{LITERATURE CITED}

Aber, J. D., D. B. Botkin and J. M. Meli1lo. 1978. Predicting the effects of different harvesting regimes on forest floor dynamics in northern hardwoods. Can. J. For. Kes. 8:306-315.

Barney, R. J. and K. Van Cleve. 1973. Black spruce fuel weights and biomass in two interior Mlaska stands. Can. J. For. Res. 3:304-311.

Bethe1, J. S. et al. 1979. Energy from Wood. A report to the Office of Technology Assessment. OTA-C-78-339. College of Forest Resources, University of Washington, Seattle, Washington. $321 \mathrm{pp}$.

Bolin, B. 1977. Changes of land biota and their importance for the carbon cycle. Science 196:613-615.

Bormann, F. A. and G. E. Likens. 1979. Pattern and Process in a Forested Ecosystem. Springer-Verlag. New York. 253 pp.

Botkin, D. B., J. F. Janak and J. R. Wallis. 1972. Some ecological consequences of a computer model of forest growth. J. Ecol. 60:849-872.

Bowen, N. G. 1978. Canada's forest inventory - 1976. Can. For. Serv. For. Manage. Inst. Inf. Rep. FMR-X-116. Ottawa, Ontario.

Bramryd, T. 1979. The effects of man on the biogeochemical cycle of carbon in terrestrial ecosystems. In: SCOPE 13. The Global Carbon Cycle. B. Bolin, E. T. Degens, S. Kempe and . . Ketner (eds.). SCOPE - International Council of Scientific Unions. John Wiley \& Sons. Chichester.

Cliff, E. P. 1973. Timber: The Renewable Material. Report to the National Committee on Materials Policy. 151 pp. U.S. Gov't. P.O. Washington, D.C.

Commission of the European Communities. 1976. Forestry problems and their implications for the environment in the member states of the European Communities. Information on Agriculture No. 25. 129 pp. European Comm. Info. Serv. Washington, D.C.

Cromack, K. Jr. 1973. Litter production and decomposition in a mixed hardwood watershed and a white pine watershed at Coweeta Hydrologic Station, North Carolina. Ph.D. thesis, University of Georgia, Athens. $160 \mathrm{pp}$.

Eckho1m, E. 1979. Planting for the future: forestry for human needs. Worldwatch Pap. 26. Worldwatch Institute. $64 \mathrm{pp}$.

Edmonds, R. L. (ed.) 1974. An initial synthesis of results in the coniferous forest biome, 1970-1973. Bul1. 7, Coniferous Forest Biome, US/IBP, Ecosystem Analysis Studies, University of Washington, Seattle, Washington. 245 pp. 
Fischer, F. 1960. Switzerland and Its Forests. A synthesis of middieEuropean forestry ideas. The College Press. Oregon State College, Corvallis. $56 \mathrm{pp}$.

Forster, R. B. 1978. Japanese forestry. The resources, industries and markets. Info. Rpt. E-X-30. Department of the Environment, Canadian Forestry Service, Policy, Analysis and Development Branch, Ottawa, Ontario.

Giordano, G. 1956. The Mediterranean Region. In: A World Geography of Forest Resources. S. Haden-Guest, J. K. Wright and E. Teclaff (eds.). pp. 317-352. The Ronald Press Co., New York.

Grantham, J. B. and T. H. Ellis. 1974. Potentials of wood for producing energy. J. For. 27:552-556.

Grier, C. C., D. W. Cole, C. T. Dyrness and R. L. Fredriksen. 1974. Nutrient cycling in 37- and 450-year old Douglas-fir ecosystems. In: Integrated Research in the Coniferous Forest Biome. R. H. Waring, and R. L. Edmonds (eds.). Pp. 25-34. Bu11. 5, Coniferous Forest Biome, US/IBP Ecosystems Analysis Studies, University of Washington, Seattle, Washington. $96 \mathrm{pp}$.

and R. S. Logan. 1977. 0ld-growth Pseudotsuga menziesii communities of a western Oregon watershed: biomass distribution and production budgets. Eco1. Monogr. 47(4):373-400.

Harris, W. F., R. A. Goldstein and G. S. Henderson. 1973. Analysis of forest biomass pools, annual primary production and turnover of biomass for a mixed deciduous forest watershed. In: IUFRO Biomass Studies. H. E. Young (ed.). pp.441-64. Coll. Life Sci. Agric., University of Maine, Orono.

Heske, F. 1938. German Forestry. Yale University Press. New Haven. 342 pp.

Hett, J. M. 1971. Land-use changes in east Tennessee and a simulation model which describes these changes for three counties. ORNL-IBP-71-8, US/IBP, Eastern Deciduous Forest Biome, Oak Ridge National Laboratory. Oak Ridge, Tennessee. 56 pp.

Josephson, H. R. and D. Hair. 1956. The United States. In: A World Geography of Forest Resources. S. Haden-Guest, J. K. Wright and E. Teclaff (eds.). pp. 149-182. The Ronald Press Co., New York.

Klopatek, J. M., R. J. O1son, C. J. Emerson and J. L. Joness. 1979. Landuse conflicts with natural vegetation in the United States. Environ. Conserv. 6: (in press).

Krumlik, J. G. 1974. Biomass and nutrient distribution in two old-growth forest ecosystems in south coastal British Columbia. M.Sc. Thesis, University of British Columbia, Vancouver, B.C. 180 pp. 
Kuichler, A. W. 1964. Manual to accompany the map -- Potential natural vegetation of the conterminous United States. American Geographical Society Spec. Pub. No. 36. 39 pp. plus appendix.

Lin, D. Y. 1956. China. In: A World Geography of Forest Resources. S. Haden-Guest, J. K. Wright and E. Teclaff (eds.). pp. 529-550. The Ronald Press Co., New York.

Long, J. N. 1976. Forest vegetation dynamics within the Abies amabilis Zone of a western Cascades watershed. Ph.D. Thesis, University of Washington, Seattle, Washington. 175 pp.

Lowenthal, D. 1956. Western Europe. In: A World Geography of Forest Resources. S. Haden-Guest, J. K. Wright and E. Teclaff (eds.). pp. 269-302. The Ronald Press Co., New York.

Mikese11, M. W. 1969. The deforestation of Mt. Lebanon. Geog. Review $59: 1-28$.

Monk, C. D., G. I. Child and S. A. Nicholson. 1970. Biomass, 1itter and leaf surface area estimates of an oak-hickory forest. Oikos 21:138-141.

Naveh, Z, and J. Dan. 1973. The human degradation of Mediterranean landscapes in Israel. In: Mediterrenean Type Ecosystems: Origin and Structure. F. diCastri and H. A. Mooney (eds.). Springer-Verlag. New York. 405 pp.

Ogawa, S. 1966. White paper on Japan's forestry industry 1965. Japan Lumber Journal, Inc., Tokyo. 325 pp.

Olson, J. S., H. A. Pfuderer and Y. W. Chan. 1978. Changes in the global carbon cycle and the biosphere. Environmental Sciences Division Pub. No. 1050. Oak Ridge National Laboratory, Oak Ridge, Tennessee. ORNL/ EIS-109. 154 pp.

Ovington, J. D. 1962. Quantitative ecology and the woodland ecosystem concept. Adv. Ecol. Res. 1:103-192.

Reed, F. L. C. \& Associates. 1978. Forest management in Canada, Volume I. Can. For. Serv. Manage. Inst. Inf. Rep. FMR-X-102. Ottawa, Ontario.

Revelle, R. and M. W. Munk. 1977. The carbon dioxide cycle and the biosphere. In: Energy and Climate. Studies in Geophysics. Panel on Energy and Climate. pp. 253-281. National Research Council, National Academy of Sciences, Washington, D.C.

Rodin, L. E. and N. I. Bazilevich. 1967. Production and Mineral Cycling in Terrestrial Vegetation. [English translation by G. E. Fogg.] Oliver and Boyd. London. 288 pp.

Schlesinger, W. H. 1977. Carbon balance in terrestrial detritus. Annu. Rev. Ecol. Syst. 8:51-81. 
Sharp, D. D., H. Leith and D. Whigham. 1975. Assessment of regional productivity in North Carolina. In: Primary Productivity of the Biosphere. H. Leigh and R. H. Whittaker (eds.). Springer-Verlag, New York.

Siegenthaler, U. and H. Oeschger. 1978. Predicting future atmospheric carbon dioxide levels. Science 199:388-395.

Spurr, S. and H. Vaux. 1974. Forest Ecology. Ronald Press Co., New York. $571 \mathrm{pp}$. Science 191:752-756.

Streyffert, K. T., A. Langsaeter and E. Saari. 1956. Northern Europe. In: A World Geography of Forest Resources. S. Haden-Guest, J. K. Wright and E. Teclaff (eds.). pp. 231-252. The Ronald Press Co., New York.

Stuiver, M. 1978. Atmospheric carbon dioxide and carbon reservoir changes. Science 199:253-258.

Sutton, W. R. J. 1975. The forest resources of the U.S.S.R.; their exploitation and their potential. Commonw. For. Rev. 54, 2:110-138.

Tansley, A. G. 1968. Britain's Green Mantle, Past, Present and Future. 2nd edittion. Revised by M. C. F. Proctor. Allen and Unwin. London. 327 pp.

Teclaff, E. 1956. East-Central Europe. In: A World Geography of Forest Resources. S. Haden-Guest, J. K. Wright and E. Teclaff (eds.). pp. 303-316. The Ronald Press Co., New York.

Tunstel1, G. 1956. Alaska. In: A World Geography of Forest Resources. S. Haden-Guest, J. K. Wright and E. Teclaff (eds.). pp. 127-148. The Ronaid Press Co., New York.

United States Department of Agriculture. 1978. Forest statistics of the United States, 1977. Review Draft, U.S. Forest. Service. Washington, D.C. 133 pp.

Van Cleve, K., L. A. Viereck and R. L. Schlentner. 1971. Accumulation of nitrogen in alder (Ainus) ecosystems near Fairbanks, Alaska. Arc. Alp. Res. 3(2):101-114.

Whittaker, R. H. and G. E. Likens. 1975. The biosphere and man. In: Primary Productivity of the Biosphere. H. Leith and R. H. Whittaker (eds.). pp. 305-328. Springer-Verlag, New York.

and G. M. Woodwe1l. 1969. Structure, production and diversity of the oak-pine forest at Brookhaven, New York. J. Ecol. $57: 155-174$. 
Wood, T. and D. B. Botkin. 1979. The Forests of New England, 1620-1970. An Ecological Perspective. A manuscript.

Woodwel1, G. M., R. H. Whittaker, W. A. Reiners, G. E. Likens, C. C. Delwiche and D. B. Botkin. 1978. The biota and the world carbon budget. Science 199:141-146.

Zon, R. 1956. The Union of Soviet Socialist Republics. In: A World Geography of Forest Resources. S. Haden-Guest, J. K. Wright and E. Teclaff, (eds.). pp. 393-420. The Ronald Press Co., New York. 
THIS PAGE

\section{WAS INTENTIONALLY \\ LEFT BLANK}


APPENDIX I

Participants in the TIE Workshop on Temperate Zone Forests and the Global Carbon Cycle.

Dr. Nelson T. Edwards

Environmental Science Division

Oak Ridge National Laboratory

Oak Ridge, Tennessee 37830

Dr. S. Gessel

College of Forest Resources

University of Washington

Seattle, Washington 98195

Dr. Pau1 Harcombe

Biology Department

Rice University

Houston, Texas 77001 .

Dr. W. F. Harris

Environmenta1 Sciences Division

Oak Ridge National Laboratory

Oak Ridge, Tennessee 37380

Dr. Joan Hett

12069 th Avenue $W$.

Seattle, Washington 98119

Dr. Jerry Melillo

The Ecosystems Center

Marine Biological Laboratory

Woods Hole, Massachusetts 02543
Dr. C. W. Ralston

School of Forestry

Duke University

Durham, North Carolina 27706

Dr. Forest Stearns

Department of Botany

University of Wisconsin-Milwaukee

Milwaukee, Wisconsin 53204

Dr. Wayne T. Swank

Cooweta Hydrologic Laboratory

Post Office Box 601

Franklin, North Carolina 28734

Dr. Orie L. Loucks

Science Director

The Institute of Ecology

Indianapolis, Indiana 46208

Dr. Thomas V. Armentano

Research Scientist

The Institute of Ecology

Indianapolis, Indiana 46208 
THIS PAGE

\section{WAS INTENTIONALLY LEFT BLANK}




\author{
APPENDIX II \\ Growth Trends in Commercial Forests of \\ North America - A Regional Analysis
}

\title{
United States
}

The United States Department of Agriculture classifies $295.3 \times 10^{6}$ ha of the land area in the U.S. as forest land (U.S.D.A. 1978). This represents approxinately $33 \%$ of the total land area. Further subdivision shows that $66 \%$ of this forested area is classified as commercial with the remaining in reserved, deferred or other forest lands (Table 1). 'Other forest lands' are the second largest area (31\%) so further knowledge of these forests is needed before detailed carbon budgets can be prepared. Much of the 'other forest'area $\left(43.0 \times 10^{6} \mathrm{ha}\right)$ occurs in interior Alaska and some areas may be reclassified as detailed surveys have not been completed. Of the remaining area, most occurs in the southern Rocky Mountains and the southwest.

The U.S. Forest Service has been maintaining national records on forest output, standing timber, etc. for over 25 years. This provides a much longer record than can be found in Canada. Thus, long-term changes and trends can be determined, along with the statistical confidence for large areas in North America, but only single data points are available for Canada.

In the U.S., there has been a steady increase in volumes of growing stock, approximately $120 \times 10^{6} \mathrm{~m}^{3}$ per year, and a decrease in land area classified as commercial timberland, averaging $20 \times 10^{4}$ ha lost each year over the past 25 years. Some land has been transferred from commercial to reserved or deferred, particularly in the west, and some to rangeland in the West Gulf and southwestern states. What is needed now is more detailed information on what land use the commercial forest has been converted to and what differences in carbon dynamics might be expected from this change.

New England

The New England region includes the states of Connecticut, Maine, Massachusetts, New Hampshire, Rhode Island and Vermont (total land area = $16.3 \times 10^{6}$ ha; $81 \%$ forested land of which $95 \%$ is classified as commercial forest, Table 1). Most of the commercial forests are stocked (98\%) and the size distribution is fairly equally divided between sawtimber, poletimber, and seedlings and saplings (Table 2). Over half of the sawtimber is in hardwood species while poletimber volume has a greater percentage of softwood species. This may be a result of harvesting practices, because in 1976 softwoods made up $62 \%$ of the harvested growing stock. It also could be a result of management, i.e., planting softwood species or controling hardwoods to increase softwood production.

The net annual growth (NAG)* of $38.3 \times 10^{6} \mathrm{~m}^{3}$ per year for New England (Table 3) is about average for the nation but a below-average harvest rate

This Appendix was prepared by Dr. Joan Hett.

* Net annual growth = the annual change in volume of sound wood in live sawtimber and poletimber trees resulting from natural causes. 
THIS PAGE

\section{WAS INTENTIONALLY LEFT BLANK}


Table 1. Areas of the major land classes in the United States (in $10^{6}$ ha).

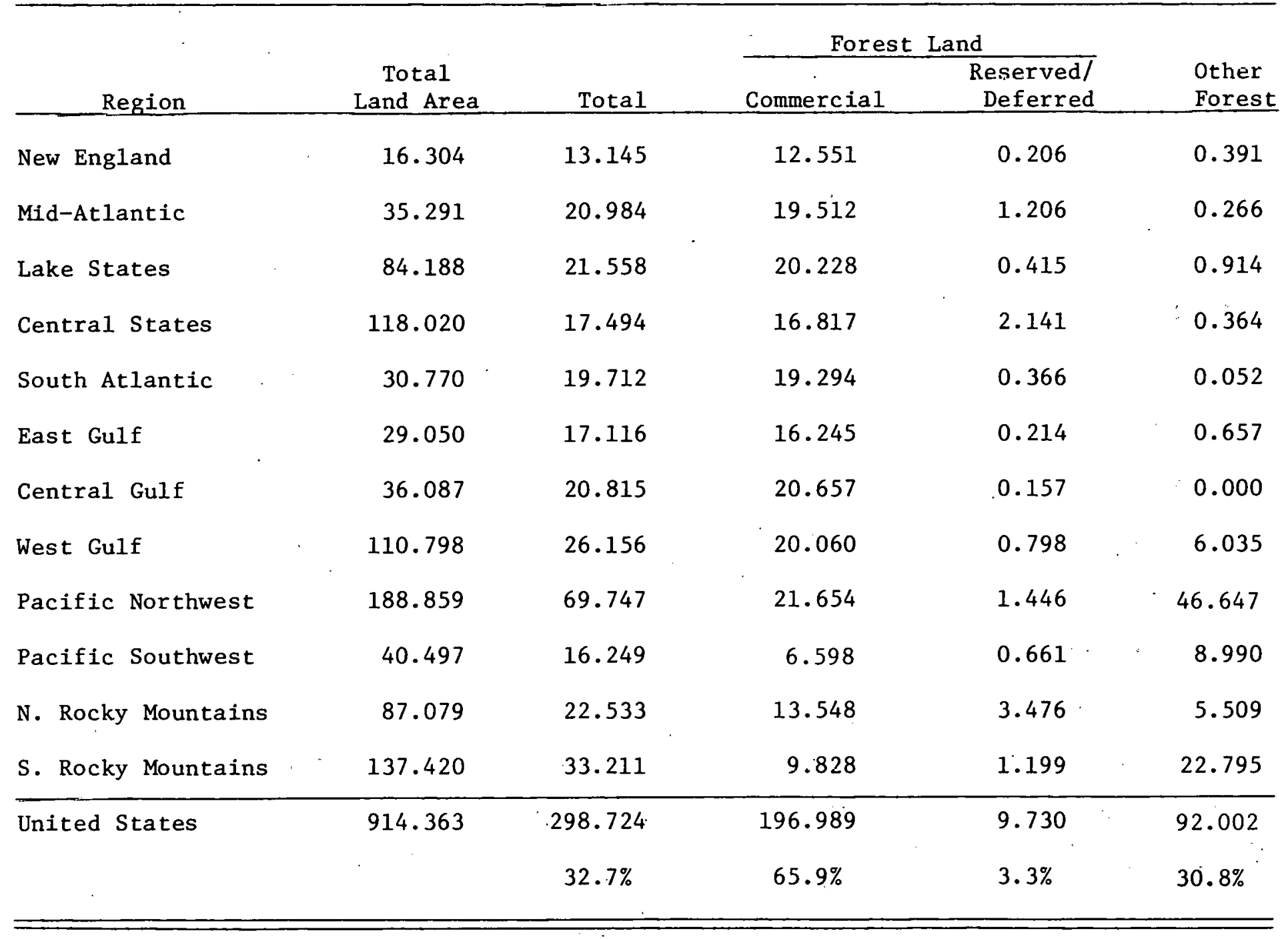

1 ha $=2.471$ acres 
Table 2. Size class distribution of commercial forest in the United States (in $10^{6}$ ha).

\begin{tabular}{|c|c|c|c|c|c|}
\hline$\because$ Region & $\begin{array}{r}\text { Sawtimber } \\
\text { Sof twood } \\
(\mathrm{dbh} \cdot 22.66 \mathrm{~cm}) \\
\text { Hardwood } \\
(\mathrm{dbh} \quad 29.94 \mathrm{~cm})\end{array}$ & $\begin{array}{c}\text { Poletimber } \\
\text { Softwood } \\
(12.7-22.86 \\
\text { Hardwood } \\
(12.7-29.94 \\
\end{array}$ & $\begin{array}{l}\mathrm{cm}) \\
\mathrm{cm})\end{array}$ & $\begin{array}{l}\text { Seedlings } \\
\text { and Saplings } \\
(0-12.7 \mathrm{~cm})\end{array}$ & $\begin{array}{l}\text { Non-S tocked } \\
\text { (Less than } \\
10 \% \text { ) } \\
\end{array}$ \\
\hline New England & 4.776 & 3.857 & & 3.804 & 0.114 \\
\hline Mid-Atlantic & 7.733 & 5.607 & & 5.415 & 0.756 \\
\hline Lake States & 4.194 & 9.365 & & 5.640 & 1.029 \\
\hline Central States & 7.004 & 4.538 & & 4.575 & 0.700 \\
\hline South Atlantic & 7.845 & 6.344 & $\therefore$ & 4.647 & 0.457 \\
\hline East Gulf & 5.460 & 5.238 & $\because$ & 4.322 & 1.226 \\
\hline Central Gulf & 5.947 & 6.397 & & 8.201 & 0.112 \\
\hline West Gulf & 8.421 & 5.202 & & 6.136 & 0.300 \\
\hline Pacific Northwest & 13.843 & 3.471 & 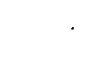 & 3.489 & 0.850 \\
\hline Pacific Southwest & 4.883 & 0.583 & & 0.807 & 0.708 \\
\hline N. Rocky Mountains. & 9.018 & 2.792 & & 1.358 & 0.380 \\
\hline S. Rocky Mountains & 6.581 & 1.946 & & 0.647 & 0.654 \\
\hline United States & 85.705 & 55.340 & & 49.043 & 7.2872 \\
\hline . & $43.5 \%$ & $28.1 \%$ & · & $24.9 \%$ & $3.7 \%$ \\
\hline
\end{tabular}

Total commercial forest land $=196.992 \times 10^{6}$ ha 
Table 3. Summary of commercial timberland data in the United States by region and biome. Data from the U.S. Forest Service (U.S.D.A. 1978).

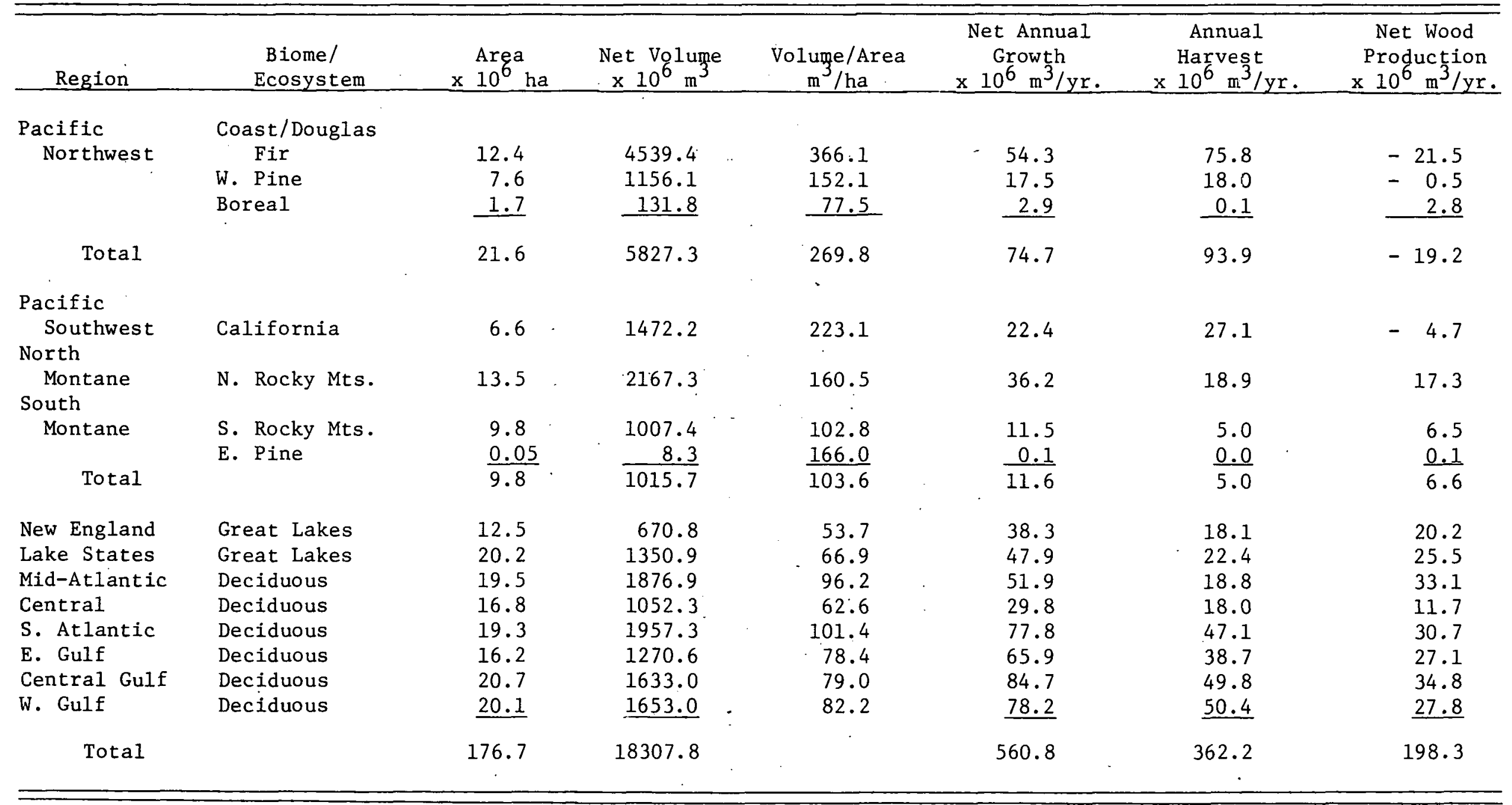


results in a fairly high wood production each year. The New England states have been steadily increasing their harvest over the past 25 years, but the NAG has doubled since 1952 and it appears these forests are acting as a sink rather than a source.

\section{Mid-Atlantic Region}

Delaware, Maryland, New Jersey, New York, Pennsylyania and West Virginia comprise the Mid-Atlantic Region ( $60 \%$ of the $35.3 \times 10^{6}$ ha is classified as forest land of which $93 \%$ is commercial; Table 1). Approximately $4 \%$ of the commercial forest is nonstocked and the remaining area is fairly equally divided between the three size classes (Table 2) with a slightly larger percentage in sawtimber. Hardwoods are the primary wood type with $87 \%$ of the net volume on commercial timberland in hardwood species of which $38 \%$ is made up of oak species while $56 \%$ of the sof twood volume is pine. Also, even though Table 2 indicates a greater volume in sawtimber, when one examines table using finer size class intervals $(5 \mathrm{~cm})$, the $17.8-22.6 \mathrm{~cm}$ softwond diameter class and the 22.9-27.7 cm hardwood diameter class (both poletimber classes) have the largest volumes.

The timber volume of the Mid-Atlantic Region (96.2 $\times 10^{6} \mathrm{~m}^{3} \mathrm{ha}^{-1}$ ) is almost double the volume found in New England. Net annual growth is higher than average and again, as in New England, a lower than average harvesting rate results in a very high net wood production. In fact, the second highest net wood production in the nation is found in this region. There has been a steady increase in both softwood and hardwood volumes over the last 25 years and hardwood volumes have increased at a rate of approximately $23 \mathrm{x}$ $10^{6} \mathrm{~m}^{3}$ per year. This region is one of the few regions to have gained forested land and has gained the greatest area of all regions, 2,475,000 hectares. Annual removals appear to follow the same trend as net annual growth, as each increased until 1970 and then the 1976 figures show a decrease in both net annual growth and annual harvest. This indicates that this region will continue to be a sink rather than a source if the forest management policies now being used are continued.

\section{Lakes States Region}

Michigan, Minnesota, North Dakota, eastern half of South Dakota and Wisconsin are all in the Lake States Region. (Total land $=84 \times 10^{6}$ ha of which $21.6 \times 10^{6}$ are classified as forest land, nearly all of which is classified as commercial forest; Table. 1 ). This region differs from the other regions in size class distribution. There is a much greater percentage of the commercial timberland area in poletimber and a higher than average percentage of the land area is nonstocked (Table 2).

Hardwoods form nearly three-quarters of the net volume on commercial land but over $31 \%$ is cottonwood and aspen - pulp species. Spruce and balsam fir are the major softwood species. Like the New England Region, this region has a lower than average volume per unit area (Table 3). However, the net annual growth is higher and the annual harvest is lower than the national average, resulting in a fairly high net annual wood production. 
The twenty-five year statistics indicate that the Lake States have lost approximately 1,060,280 hectares of commercial timberland but both hardwood and softwood have shown a continued increase in net volume as well as an increase in annual removals of both.

\section{Central States Region}

The Central States Region includes the states of Illinois, Indiana, Iowa, Kansas, Kentucky, Missouri, Nebraska and Ohio. East of the Rocky Mountains, this region has the largest land area $\left(118 \times 10^{6}\right.$ ha), but only $15 \%$ of this is forested $\left(17.5 \times 10^{6} \mathrm{ha}\right)$. Also, this region has the second highest land area in reserved or deferred status, leaving $12 \%$ of the forested land unavailable for harvest (Table 1).

Sawtimber occupies one and a half times the area occupied by the other size classes (Table 2). Hardwoods, primarily oaks, form the major part of the volume in the sawtimber class; while pines are the major softwood; but much of their volume is in the smaller classes or just entering the sawtimber classification.

The Central States have the lowest volume per unit area of all the Eastern Deciduous Forest biome and only New England has lower volume if the entire country is examined (Table 3). Net annual growth is lower in this region than any other area other than California and interior Alaska. Although the annual harvest is below average, the low growth produces a fairly low net annual wood production but the region still forms a $\mathrm{CO}_{2}$ sink rather than a source.

\section{South Atlantic Region}

The South Atlantic Region has three states, North and South Carolina and Virginia (total land area $=30.8 \times 10^{6}$ ha of which $19.7 \times 10^{6}$ ha is forested and virtually all is commercial forest; Table 1). This region is in the Eastern Deciduous Forest but nearly $32 \%$ of the commercial timber land is in pine species. Most of the timber is in saw and poletimber classes (Table 2) but with hardwood spectes having a fairly equal distribution of net volume between diameter classes and softwood species, primarily pine, more heavily weighted to the smaller diameter classes.

The South Atlantic Region has more net volume of wood than any other area except the Coastal/Douglas-fir zone of the Pacific Northwest and the Northern Rocky Mountains Region (Table 3). However, volume per unit area is not as high as most areas in the west but is still the highest in the East: The highest net growth yields the third highest net wood production in the nation even though the annual harvest is high. Since there has been a $60 \%$ increase in net annual growth over the last 25 years and the annual harvest has remained somewhat constant, this region is definitely a carbon sink and should continue to remain so unless there is a major change in forest management policy. 
East Gulf Region

Florida and Georgia comprise the East Gulf Region $\left(29 \times 10^{6}\right.$ ha of land area, of which $59 \%$ is forested, all but $5 \%$ commercial timberland; Table 1). Although the southern portion of Florida is subtropical, statistics do not separate out this area, so the entire East Gulf Region is considered part of the Eastern Deciduous Forest, even though $61 \%$ of the growing stock volume is softwood.

There is a fairly even distribution of size classes in this region (Table 2)., However, examining net volume distribution by diameter class reveals much of the smaller classes have pine specles contributing most of the volume while hardwood species such as sweet gum (Liquidambar styraciflua) and tupelo (Nyssa sylvatica) volumes are higher in the sawtimber diameter classes. The fact that these softwood species are still in the small diameter classes may explain the fairly. low volume per unit area in this region (Table 3). Net annual growth is high, but so is the annual. harvest. But even with this high harvesting rate, there is still a positive net wood production each year, thus this region is also acting as a carbon sink.

\section{Central Gulf Region}

Included in the Central Gulf Region are the states of Alabama, Mississippi and Tennessee and all lie in. what has ben defined as the Eastern Deciduous Forest (forested land area is $20.8 \times 10^{6}$ ha or $58 \%$ of the total land area; Table 1). Nearly all the forested area is considered commercial and $72 \%$ of the area is forested by oak-pine, oak-hickory or oak-gum-cypress forest types with loblolly-shortleaf pine being the major softwood forest type.

Size class distributions show a much higher percentage of the growing stock in the pole and seedling and sapling classes. Net volumes of growing stock have $45 \%$ of the volume in sotfwood species, mostly in the smaller diameter classes. Differing slightly from the other regions in the Declduous Forest, the Central Gulf Region has a large percentage of its hardwood volume in diameter classes less than $32.8 \mathrm{~cm}$ indicating young growing hardwood stands.

Total net volume for this region is about average for the Deciduous Forest and probably because of the large area of young growing forests in this region, we find the highest net annual growth. Although there is a high annual harvest, this area has the highest net wood production in the nation. The 25 year statistics indicate an increase in net annual growth in both soft- and hardwood species with the softwoods increasing more rapidly. This trend is also true for annual removals of softwoods but the amount of hardwood harvested in 1976 is most the same as it was in 1952, with slightly less volumes harvested in 1962 and 197.0. The balance is still weighted on the side of growth and the forests of this region are acting as sinks for carbon. 
West Gulf Region

The West Gulf, Arkansas, Louisiana, Oklahoma and Texas, is one of the largest land areas in the United States, but the 110.8 million hectares of land area only have 26.1 million hectares of forested land $(24 \%)$ and $23 \%$ of this forested area is classified as 'Other Forest'. A majority of the forests are oak types, although loblolly pine-shortleaf pine types make up $26 \%$ of the area.

Sawtimber dominates the size class distribution in this region but the sapling and seedling class is the second largest class. In this region, the hardwood volumes are fairly evenly divided between pole- and small sawtimber as are the softwood species. Pines are the major softwoods while oaks make up the major portion of the hardwood volume.

This region has the third highest volume of growing stock the Deciduous Forest. Net annual growth and annual removal are very high. This results in a positive net wood production indicating that these forests are storing carbon. This region is also losing land area from the Commercial forests. Since 1952, over 1,400,000 hectares have been converted from forest to some other land use. An understanding of what this means to the carbon budget for this region is necessary before an adequate national budget can be attempted.

\section{Pacific Northest Region}

Alaska, Oregon and Washington are included in the Pacific Northwest Region forming the largest region defined by the U. S. Forest Service. Because of its geographic size and topgraphic variability, three major forest zones can be defined: Coast/Douglas-fir Zone (57\% of the forest area) which extends north and south from southern Oregon to southeastern Alaska along the Pacific coast, and west of the Cascade Mountains in Washington and Oregon and the Coast Mountains in British Columbia and southeastern Alaska; north of this zone is the Boreal Forest of interior Alaska, ( $8 \%$ ) and east of the Cascade Mountains in Oregon and Washington, is the western Pine Zone (35\%). Together these forests occupy $69.7 \times 106$ ha or $37 \%$ of the total 1and area. Only $31 \%$ of the forest is classifled as Commercial.

0ld growth forests dominate the size class distribution (66\% of the area) and a more detailed examination of tables showing net volume diameter class shows most of the volume is found in softwood species. (primarily Douglasfir, Pseudotsuga menziesii) in the $73.7+\mathrm{cm}$ class. This predominance of oldgrowth forests in very large size classes is probably the reason why this region of high volumes and high net annual growth rates (Table 3) has a negative net wood production. A different analysis (not shown in this report) indicates that most of this deficit is in western Oregon $\left(-16.4 \times 10^{6} \mathrm{~m}^{3} / \mathrm{ha} / \mathrm{yr}\right)$. Therefore, the Pacific Northest is a source of carbon at the present time. However, the Pacific Northest has lost about 1,150,00 hectares of forest land over the last 25 years and there has been a $33 \%$ increase in net annual growth with only a $28 \%$ increase in annual harvest. This seems to indicate, that in time, this region will no longer be a large cabron source will follow the same trend as the other forest regions. 


\section{Pacific Southest Region}

The states of Hawali and California form the Pacific Southest Region. For the purposes of this report, however, only data from California will be used. Of the total of $40.5 \times 10^{6}$ ha of land in the state, $16.2 \times 10^{6}$ ha are forested but only $6.6 \times 10^{6}$ ha support commerical forests and nearly $9 \times 10^{6}$ are classified as 'other forest' (Table 1). California is a very diverse state ecologically and using values averaged across the entire state can be very misleading as the redwood forest of the west coast have some of the largest volumes found in the world yet shows overall net volumes are lower than that of Northern Rocky Mountain Region (Table 3). 'However, volume per unit area of this region is the second highest in the nation.

Size classes show a distribution similar to that found in the Pacific Northwest -- high percentage of old growth timber (Table 2). New volume of growing stock is almost entirely softwood and most of the softwood volume is made up of Douglas-fir and true firs (Abies spp). This Region if also similar to the Pacific Northwest in that it is characterized by a deficit in net wood production. Harvest totalled $4.7 \times 10^{6} \mathrm{~m}^{3}$ more wood than growth in 1976 but as the 25 year trend is a decrease in annual removals and an increase in net annual growth, this deficit may soon be erased. But at the moment, the forests of California are a carbon source.

Northern Rocky Mountain Region

Idaho, Montana, the western half of South Dakota and Wyoming form the Northern Rocky Mountain Region. A fairly large area ( $87.1 \times 10^{6}$ ha), it has a relatively small proportion of its area in commercial forest. Only $26 \%$ of the area is forested, of which $60 \%$ is commercial forest and $24 \%$ is 'other forest'. This region also has the largest area set aside as reserved or deferred forest, $3.5 \times 10^{6}$ ha and since 1952 , this region has lost more area from commercial forests than any other region. It will be necessary to determine what this change in land status is and what it means in regard to carbon dynamics.

As in the rest of the western regions, sawtimber dominates the size class distribution ( $T a b l e ~ 2)$. Softwoods form $98 \%$ of the net volume and most of this growing stock volume is Douglas-fir which has a fairly even distribution throughout the diameter classes as do most of the other species. The reason for the heavy weighting in the sawtimber class is that most of the softwood species grow to very large diameters so seven, $5 \mathrm{~cm}$ size classes are summed in the sawtimber class compared to three in the poletimber class.

Net volume of growing stock as well as the volume per unit area in this region is the second highest in the nation behind the Pacific Northwest. However, even though the net annual growth is lower than the national average, so is the annual removal, producing a net wood production that is close to the national average with a positive net wood production. Therefore, these forests are acting as a carbon sink. 
Southern Rocky Mountain Region

The Southern Rocky Mountain Region includes Arizona, Colorado, Nevada, New Mexico and Utah and is the second largest region in the United States $\left(137.4 \times 10^{6}\right.$ ha in total land area, $33.2 \times 10^{6}$ ha forested of which $9.8 \times$ $10^{6}$ ha are considered commerclal forest; Table 1).

As in other western regions, sawtimber is the dominant size class (Table 2). Although sotfwoods make up most of the volume, $13 \%$ of the volume is in cottonwood and aspen and much of their volume is in the smaller size classes.

A11 the western regions, even the fairly dry and warm southern Rocky Mountains, have volumes per unit area higher than any eastern region (Table 3 ). But net annual growth shows the reverse, for all the west except the productive Pacific Northwest probably because of the large areas of old growth timber in the west which may have a net ecosystem productivity approaching zero compared to the productive second growth forests of the east. The southern Rocky Mountains has a low net annual growth, lowest in the nation except for interior Alaska, but combined with a very low annual harvest, it has a positive net wood production. Thus the only forest regions in the west which can be considered carbon sinks are those found in the Rocky Mountains and interior Alaska.

\section{Canada}

The most recent Canadian data has been analyzed by province and territory (Bowen 1978, Reed \& Associates 1978). Although political boundaries do not often coincide with ecological ones, for the purposes of this report, it is necessary to present the data as it has been anglyzed. Forest land in Canada occupies about $37 \%$ of the tgtal $922 \times 10^{6}$ ha land area in the nation. Within this $342 \times 10^{6}$ ha, $198 \times 10^{6}$ is classified as productive forest, $115 \times 10^{6}$ as unproductive forest and nearly $10 \times 10^{6}$ is in a reserved classification (Table 4). The reserved forest is "forest land that by law is not so available".

Forest inventory in Canada has not been completed but at the time of the reports, nearly $93 \%$ of the production forest 1 and had been inventoried $\left(293 \times 10^{6} \mathrm{ha}\right)$ and as the data in Table 5 indicates there are s.till many gaps in the available data. However, not all of the inventoried land is productive, 1.e., "capable of producing a merchantable stand within a reasonable length of time". Wood volumes reported are those on lands classified as stocked, productive forest lands and total $19.3 \times 10^{9} \mathrm{~m}^{3}$ on $174.5 \times 10^{6}$ ha. This value includes both the economically accessible and inaccessible timber $\left(2.05 \times 10^{9} \mathrm{~m}^{3}\right.$ is inaccessible and occurs on $19 \%$ of the total productive forest land).

Data on allowable cut, depletion by cutting and depletion by fire are not included in the data reported, but the authors advise caution in using the reported values because of data gaps, different methods of calculating values, etc. Bowen (1978) reports an annual allowable cut of 
Table 4. Areas of the major land classes in Canada (in $10^{6}$ ha).

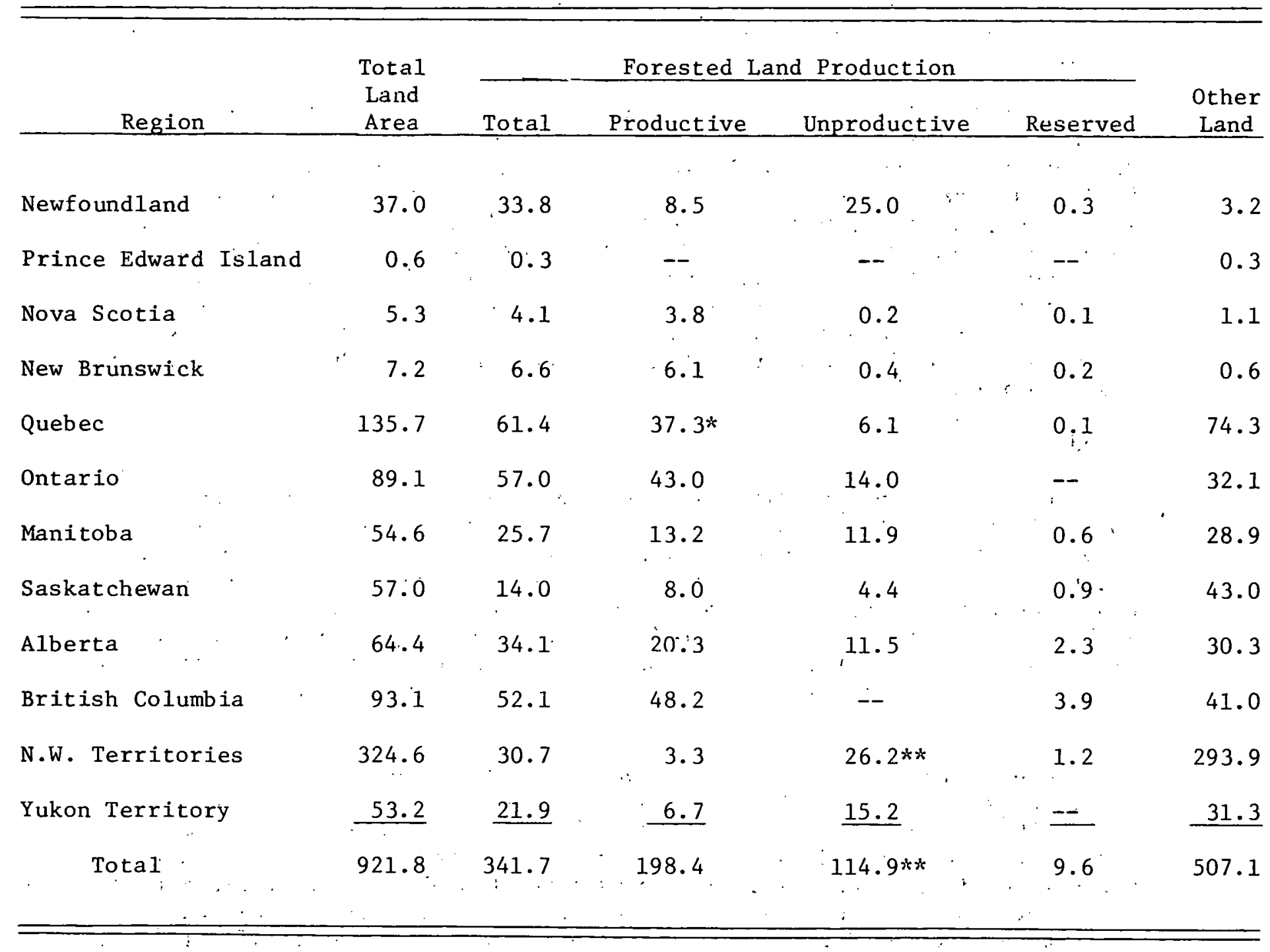

* Incomplete data.

* Reported values do not balance so $20.0 \times 10^{6}$ ha has been added to make values seem more realistic. 
Table 5. Distribution of gize classes on productive and reserved forested land of Canada (in $10^{6} \mathrm{ha}$ ).

\begin{tabular}{|c|c|c|c|c|c|c|}
\hline Province & Total & Potential & $\begin{array}{c}\text { Regeneration } \\
\text { Ht }<1 \mathrm{~m}\end{array}$ & Immature & Mature & $\begin{array}{c}\text { Uneven } \\
\text { Aged }\end{array}$ \\
\hline Newfoundland & 8.7 & $\bullet$ & $\bullet$ & 0.9 & 4.0 & $\bullet \bullet$ \\
\hline Nova Scotia & 3.9 & 1.0 & $\bullet \bullet$ & 1.5 & 1.2 & 0.1 \\
\hline New Brunswick & 6.1 & 0.4 & 0.4 & 0.9 & 4.1 & 0.3 \\
\hline Quebec & 37.3 & 3.5 & 4.9 & 9.8 & 4.9 & 14.1 \\
\hline Ontario & 43.0 & 3.3 & 4.2 & 13.4 & 21.8 & 0.2 \\
\hline Manitoba & 13.6 & 1.8 & 1.0 & 8.3 & 2.3 & $\bullet$ \\
\hline Saskatchewan & 9.3 & 0.6 & 2.5 & 2.9 & 2.6 & $\bullet$ \\
\hline Alberta & 22.5 & 5.9 & 2.0 & 10.9 & 1.6 & $\bullet$ \\
\hline British Columbia & 52.1 & 4.8 & $\bullet$ & 21.5 & 25.6 & $\bullet$ \\
\hline N.W. Territories & 3.8 & 0.6 & $\bullet \bullet$ & 2.1 & 1.1 & $\bullet \bullet$ \\
\hline Yukon Territory & 6.7 & 1.8 & $\underline{0.3}$ & 3.9 & 0.7 & - \\
\hline Total & 207.0 & 23.7 & 15.3 & 76.1 & 6.99 & 14.7 \\
\hline$\because$ & & & $\therefore$ & & & \\
\hline
\end{tabular}

- Insufficient or missing data. 
$276 \times 10^{6} \mathrm{~m}^{3}$ per year of which by rough estimate, $132 \times 10^{6} \mathrm{~m}^{3}$ was cut each year. Reported fires consumed $10.6 \times 10^{6} \mathrm{~m}^{3}$ so if you subtract the loss from fire and cutting, Canada has a net wood production of $133 \times 10^{6} \mathrm{~m}^{3}$ each year.

British Columbia

British Columbia has $52.1 \times 10^{6}$ ha of forested land with $48.2 \times 10^{6}$ ha or $93 \%$ considered productive and the remaining $7 \%$ in a reserved classification (Table 4). Of this available forest area, $40.6 \times 10^{6}$ ha are economically accessible and mature forests occupy $25.6 \times 10^{6}$ ha or $63 \%$. These mature forests have a total net volume ${ }^{*}$ of $8.08 \times 10^{9} \mathrm{~m}^{3}$ of which less than $1 \%$ is harvested annually.

Data presented in the referenced material divides the province into four zones; coast, southern interior, central interior and northern interior. These zones, although still political, have a more ecological basis with the coast zone having high precipitation and moderate temperatures. The mean annual increment (MAI) here is $5.32 \mathrm{~m}^{3} /$ ha/yr compared to $1.82,1.82$, and 1.12 for the southern, central and northern interior zones respectively (Table 6 However, average MAI's for an entire zone can be misleading as Smith's case study on an area near Vancouver indiçates (Reed \& Associates, 1978b). He found MAI's varied from 1.26 to $8.25 \mathrm{~m}^{3} / \mathrm{ha} / \mathrm{yr}$ depending upon site classification while the study area averaged $5.39 \mathrm{~m}^{3} / \mathrm{ha} / \mathrm{yr}$.

The annual allowable cut (AAC) calculated for the entire province is $99.4 \times 10^{6} \mathrm{~m}^{3}$ of which approximately 68.1 million $\mathrm{m}^{3}$ is harvested leaving a physical reserve of $31.2 \times 10^{6} \mathrm{~m}^{3} / \mathrm{yr}$. Ninety percent of the AAC is harvested in the coast zone although only $50 \%$ of the physical reserve in this zone is economically accessible. In the southern interior, $78 \%$ of the AAC is harvested annually and $80 \%$ of the physical reserve is believed to be economically accessible. About half of the forests in the central zone are either too remote or are economically inaccessible while $80 \%$ of the northern zone is classed as inaccessible.

The authors note that there is considerable pressure to review and possibly lower the AAC in the coast zone and they feel a 10-20\% reduction would eliminate the presently calculated timber reserves in both the coast and the southern interior zones.

Ecologically, the coast zone is part of the Douglas-fir region described in Washington, Oregon and southeastern Alaska. The interior zones are most similar to the northern Rocky Mountain forests to the south and grade gradually into a Boreal forest in the north.

\section{$\underline{\text { Alberta }}$}

Not all the Alberta inventory has been completed and data presented here are often based on aerial photographs that are 7-20 years old. Detailed

\footnotetext{
${ }^{*}$ Net volume = net merchantable volume or gross merchantable volume less volume of decayed and defective wood.
} 
Table 6. Summary of forest inventory data for Canada in 1976. From Reed \& Associates (1978) and Bowen (1978).

\begin{tabular}{|c|c|c|c|c|c|c|c|c|}
\hline \multirow[b]{2}{*}{ Province } & \multirow[b]{2}{*}{ Biome } & \multirow{2}{*}{$\begin{array}{l}\text { Area of } \\
\text { Mature } \\
\text { Timber } \\
\times 10^{6} \text { ha } \\
\end{array}$} & \multirow{2}{*}{$\begin{array}{l}\text { Volume } \\
\text { Mature } \\
\text { Timber } \\
\times 10^{6} \mathrm{~m}^{3} \\
\end{array}$} & \multirow{2}{*}{$\begin{array}{c}\text { Bole } \\
\text { Volume } \\
\text { Per Area } \\
\times 10^{6} \mathrm{~m}^{3} \text { ha } \\
\end{array}$} & \multirow[b]{2}{*}{$\mathrm{m}^{3} \begin{array}{c}\mathrm{MAI} \\
\mathrm{ha} / \mathrm{yr}\end{array}$} & \multicolumn{3}{|c|}{$\left(10^{6} \mathrm{~m}^{3} / \mathrm{yr}\right)$} \\
\hline & & & & & & $\begin{array}{c}\text { Annual } \\
\text { Allowable } \\
\text { Cut } \\
\end{array}$ & $\begin{array}{l}\text { Average } \\
\text { Harvest }\end{array}$ & $\begin{array}{c}\text { Physical } \\
\text { Reserve }\end{array}$ \\
\hline $\begin{array}{l}\text { British } \\
\text { Columbia }\end{array}$ & $\begin{array}{l}\text { Coast } \\
\text { N. Rocky Mts. } \\
\text { Boreal } \\
\quad \text { Total }\end{array}$ & $\begin{array}{r}5.5 \\
17.1 \\
3.0 \\
25.7\end{array}$ & $\begin{array}{c}3353.2^{1} \\
4218.6 \\
511.4 \\
8083.2\end{array}$ & $\begin{array}{l}612.7 \\
246.3 \\
167.7 \\
315.1\end{array}$ & $\begin{array}{l}5.3 \\
1.8^{3} \\
1.1 \\
2.0\end{array}$ & $\begin{array}{r}37.2 \\
55.2 \\
7.0 \\
99.4\end{array}$ & $\begin{array}{c}33.3 \\
34.8 \\
n \\
68.2\end{array}$ & $\begin{array}{r}3.9 \\
20.1 \\
7.0 \\
31.2\end{array}$ \\
\hline Alberta & $\begin{array}{l}\text { N. Rocky Mts. } \\
\text { Boreal. } \\
\text { Total }\end{array}$ & $\begin{array}{r}4.6 \\
11.8 \\
16.4\end{array}$ & $\begin{array}{r}531.7^{2} \\
1164.7 \\
1696.4\end{array}$ & $\begin{array}{r}114.7 \\
99.0 \\
103.5\end{array}$ & $\begin{array}{l}2.0_{3}^{3} \\
1.6^{3} \\
1.8\end{array}$ & $\begin{array}{r}7.6 \\
17.3 \\
24.9\end{array}$ & $\begin{array}{l}2.4 \\
4.4 \\
6.8\end{array}$ & $\begin{array}{r}5.2 \\
13.0 \\
18.1\end{array}$ \\
\hline Saskatchewan & Boreal & 7.9 & $529 \cdot 3^{2}$ & 67.4 & 1.0 & 7.8 & 2.8 & 4.9 \\
\hline Manitoba & $\begin{array}{l}\text { Boreal } \\
\text { Mixed } \\
\text { Total }\end{array}$ & $\begin{array}{l}1.9 \\
0.03 \\
2.0\end{array}$ & $\begin{array}{r}188.0 \\
0.6 \\
188.5\end{array}$ & $\begin{array}{l}96.8 \\
22.8 \\
95.9\end{array}$ & $\begin{array}{l}1.5^{3} \\
1.1 \\
1.5\end{array}$ & $\begin{array}{l}7.5 \\
0.03 \\
7.6\end{array}$ & $\begin{array}{l}2.1 \\
--.1\end{array}$ & $\begin{array}{l}5.5 \\
0.03 \\
5.5\end{array}$ \\
\hline Ontario & $\begin{array}{l}\text { Transition } \\
\text { Boreal } \\
\text { Great Lakes \& }\end{array}$ & $\begin{array}{r}7.0 \\
23.5\end{array}$ & $\begin{array}{l}494.1^{2} \\
2644.9\end{array}$ & $\begin{array}{r}71.1 \\
112.7\end{array}$ & $\begin{array}{l}0.8 \\
1.3^{3}\end{array}$ & $\begin{array}{r}3.5 \\
25.8\end{array}$ & $\begin{array}{l}0.002 \\
15.2\end{array}$ & $\begin{array}{r}3.5 \\
10.6\end{array}$ \\
\hline & $\begin{array}{l}\text { Deciduous } \\
\text { Total }\end{array}$ & $\begin{array}{r}9.9 \\
39.9\end{array}$ & $\begin{array}{r}957.6 \\
4106.7\end{array}$ & $\begin{array}{r}96.9 \\
102.8\end{array}$ & $\begin{array}{l}1.4 \\
1.3\end{array}$ & $\begin{array}{r}6.6 \\
35.9\end{array}$ & $\begin{array}{r}3.7 \\
18.9\end{array}$ & $\begin{array}{r}2.8 \\
17.0\end{array}$ \\
\hline Quebec & $\begin{array}{l}\text { Borea1 } \\
\text { Great Lakes } \\
\quad \text { Total }\end{array}$ & $\begin{array}{l}24.5 \\
21.3 \\
45.8\end{array}$ & $\begin{array}{l}1274.4^{1} \\
1278.7 \\
2553.1\end{array}$ & $\begin{array}{l}52.1 \\
59.9 \\
55.7\end{array}$ & $\begin{array}{l}1.2^{3} \\
1.4^{3} \\
1.3\end{array}$ & $\begin{array}{l}26.8 \\
26.1 \\
52.9\end{array}$ & $\begin{array}{r}8.9 \\
23.6 \\
32.5\end{array}$ & $\begin{array}{r}18.0 \\
2.5 \\
20.4\end{array}$ \\
\hline
\end{tabular}


Table 6. Continued.

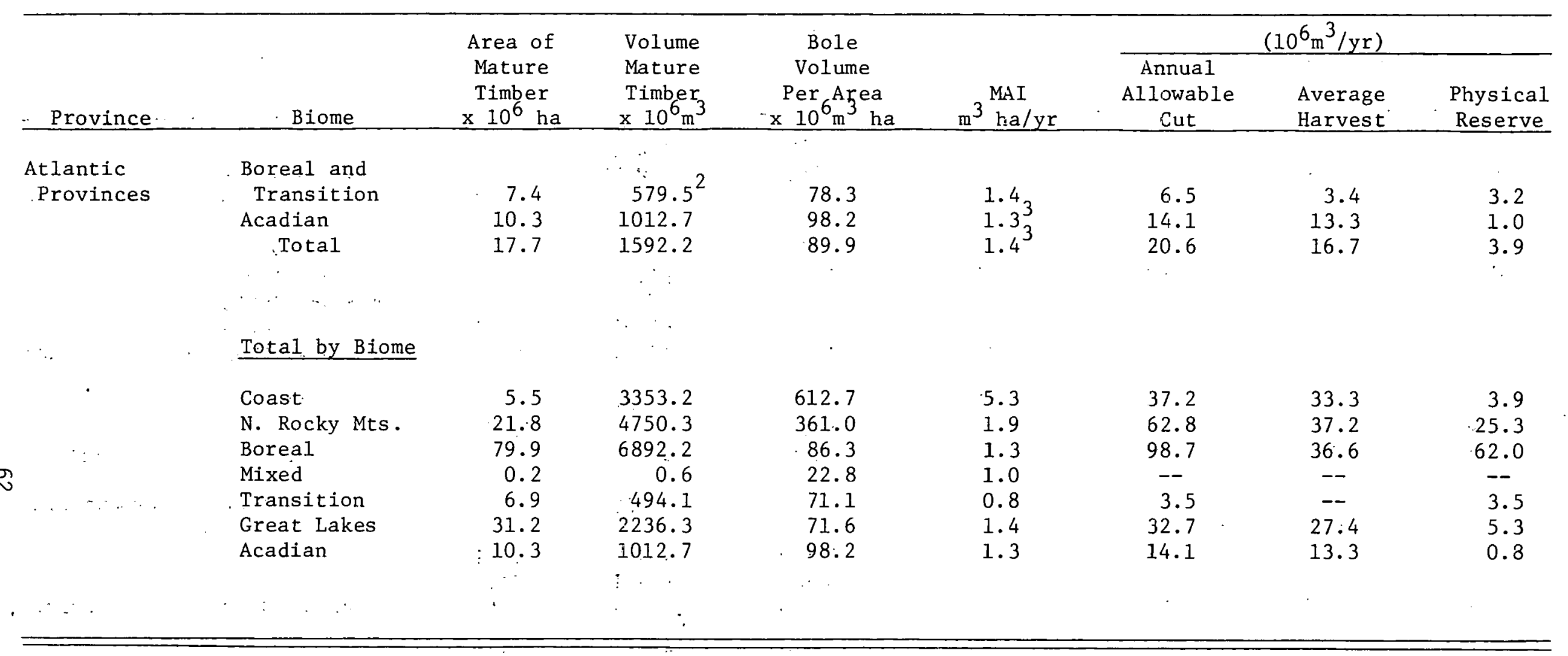

1 Net

-2. Gross

3 Average $\frac{\text { Total MAI }}{\text { Num. of Zones }}$ 
forest inventory is supposed to be complete by 1986 and the authors have used interim data wherever possible. There is also an apparent discrepancy in the data between summary tables in one publication and the tables in another. But of the $34.1 \times 10^{6}$ ha of forested land in the province ( $53 \%$ of the total land area), $0.23 \times 10^{6}$ ha are reserved and approximately 11.5 are unproductive. of the remaining, $16.4 \times 10^{6}$ ha are mature productive forest having a gross volume of $1.7 \times 10^{9} \mathrm{~m}^{3}$

Three forested zones have been defined, the western foothills which included the southwest region of the province, the north central area which corresponds roughly to the same latitude as the central interior of B.C. and third zone which is the most northerly region of the province. The MAI's decrease as you precede north and range from 2.03 to 1.40 with an average of $1.75 \mathrm{~m}^{3} /$ ha/year.

The total AAC for the province is $24.9 \times 10^{6} \mathrm{~m}^{3}$ of which approximately $6.8 \times 10^{6}$ is harvested each year leaving a physical reserve of approximately $18.1 \times 10^{6} \mathrm{~m}^{3} /$ year. Fire has resulted in vast areas of immature timber in the north central and northern zones and it is assumed as these forests mature, the AAC will be increased tremendously. Accessibility of these. forests varies--essentially all the volume remaining in the foothills zone is accessible while $30 \%$ of the reserves in the north central and $50 \%$ of the reserves in the northern zones are considered economically inaccessible at this time.

\section{Saskatchewan}

Only the northern portion of the province has forested land and a small fraction of this total $\left(14.0 \times 10^{6} \mathrm{ha}\right)$ is still uninventoried. Commercial productive forest consists of $7.8 \times 10^{6}$ ha. Four zones are recognized with 1-3 lying east to west through the central part of the province: and roughly corresponding in latitude to the north central zone of Alberta. The fourth zone--Northern Reconnaissance Zone, includes the northern portion of the province and constitutes $54 \%$ of the forested land area but all forests in this zone are considered inaccessible economically.

Fire has played an important role in the age structure of the forest in this province. In 19.37, $74 \times 10^{3}$ ha of productive forest burned and an estimated $766 \times 10^{3} \mathrm{~m}^{3}$ of growing stock was destroyed. These fires may result in a reconsideration of the AAC in zone 2 where fire damage was most severe.

Productive mature forests of Saskatchewan have a gross volume of growing stock of $529.3 \times 10^{6} \mathrm{~m}^{3}$ and MAI's vary from 1.17 in the east to 0.85 in the west with an average of $0.99 \mathrm{~m}^{3} / \mathrm{ha} /$ year. The AAC is $7.7 \times 10^{6} \mathrm{~m} /$ year of which $36 \%$ is harvested leaving a reserve of $4.9 . \times 10^{6} \mathrm{~m}^{3} /$ year. Over $80 \%$ of the commercial forest in zones $1-3$ is considered economically accessible.

Manitoba

Fifty-two percent $\left(25.7 \times 10^{6}\right.$ ha) of the province of Manitoba is forested. 
Productive forest lands occupy $13.2 \times 10^{6}$ ha and mature timber is found on $2.0 \times 10^{6}$ ha with a net volume of $189.5 \times 10^{6} \mathrm{~m}^{3}$.

Four zones have been defined in this province but zone 1 is not economically accessible. Zone 2 is the most northerly and corresponds approximately to zone 1 in Saskatchewan. Zone 3 runs diagonally across the province with a NW-SE trend and zone 4 is the area in the extreme southwestern corner. All the timber in the three zones is considered accessible.

MAI's range from 1.05 in zone 4 through 1.26 in zone 1 to 1.61 in both zones 2 and 3 . The AAC is $7.5 \times 10^{6} \mathrm{~m}^{3} /$ year with an average harvest of 2.1 leaving a physical reserve of $5.5 \times 10^{6} \mathrm{~m}^{3} / \mathrm{ha} /$ year.

\section{Ontario}

The second largest province in Canada, Ontario, also has the second largest area in mature timber; $39.9 \times 10^{6}$ ha with $4106: 7 \times 10^{6} \mathrm{~m}^{3}$ gross volume. The four zones subdividing the timberland are approximate ecological divisions. Zone 1 in northwest includes forest that is transitional between the boreal forest to the south and the tundra to the north. Zones 2 and 3 include mostly boreal forest, although there are some of the elements of the Great Lakes Forest found along the southern borders, particularly in zone 2, the more westerly of the two zones. In zonie 4, the southeastern portion of the province, one finds primarily Great Lakes Forest with a small area of Deciduous Forest in the south.

MAI's vary from 0.84 in the northern zone to $1.44 \mathrm{~m}^{3} / \mathrm{ha} /$ year in the south. A total AAC for the province is calculated at $35.9 \times 10^{6} \mathrm{~m} /$ year of which $53 \%$ is actually harvested each year, leaving a physical reserve of $17.0 \mathrm{~m}^{3} /$ year. The authors estimate that all the timber included in the AAC is economically available in zones 3 and 4 while zone 2 has about $20 \%$ inaccessible and zone 1 has at least 50\% inaccessible economically.

Although the percentage of hardwood growing stock volume is similar to Alberta and Saskatchewan (40\%), there is a greater percentage of nonpulp species such as maple and birch in Ontario. (On crown land in Alberta, $100 \%$ of the hardwood species is poplar and in Saskatchewan poplar and aspen make up $84 \%$ ) These differences in hardwood species will play an important role in determining total carbon in these forests, as the amount of forest residue left on the site may differ considerably between pulp and non-pulp species and the turnover times will also be different as pulp species are susally harvested at a much younger age, thus increasing the rate at which carbon is removed from the site.

Quebec

The largest province in Canada, Quebec, also has the largest area in mature timber, $45.8 \times 10^{6}$ ha. However, it is third behind B.C. and Ontario in volume of mature timber $\left(2553.1 \times 10^{6} \mathrm{~m}^{3}\right)$. Because of the large land mass, much of which is in boreal forest; Quebec has the lowest volume per unit area of all ten provinces $\left(55.7 \times 1.0^{6} \mathrm{~m}^{3} / \mathrm{ha}\right.$ ). (Note: Ontarto's volumes 
are gross values while B.C. reports net volumes.)

The province has four zones. Zones 1 and 2 are the more northerly with zone 1 east of zone 2 and both lie in the Boreal Forest. The other two zones follow the St. Lawrence River with zone 3 the more westerly both fall in the Great Lakes Forest. MAI's vary from 1.12 in zone 1 to 1.53 in zone 3 with an.average of $1.26 \mathrm{~m}^{3} / \mathrm{ha} /$ year for the entire province. These figures show the lower growth potential in the northern Boreal Forest compared to the Great Lakes Forest to the South.

The AAC is $52.9 \times 10^{6} \mathrm{~m}^{3} /$ year of which 32.5 is harvested. This leaves a physical reserve of $2.04 \times 10^{6} \mathrm{~m}^{3}$ /year, however, there are no data on loss from fire or insects although Quebec has a severe spruce budworm problem. So before any final estimate of carbon for this province can be made, the role of fire and insects must be determined. About $30 \%$ of zone 1 and $60 \%$ of zone 2 are economically accessible compared to $100 \%$ of both zones 3 and 4 .

Twenty five percent of the mature wood volume is made up of hardwood species, of which $60 \%$ of the volume is birch and $35 \%$ aspen.

\section{Atlantic Provinces}

The data from the three maritime provinces, New Brunswick, Nova Scotia and Prince Edward Island are analyzed with Newfoundland and Laborador. Nova Scotia, PEI and New Brunswick can be classified together ecologically (Rowe 1959) and they differ significantly from Newfoundland and Laborador. Rowe classifies the first three provinces as Acadian Forest while the Laborador and Newfoundland are intermingled Boreal and Transition Forests. For this report, we have grouped NS, NB, and PEI as one unit and Newfoundland and Laborador as another. (Note: the referenced material only gives data on "better" forests in Laborador.)

Total area of Acadian Forests is $10.3 \times 10^{6}$ ha which has a gross volume of $1012.7 \times 10^{6} \mathrm{~m}^{3}$ or $98.2 \times 10^{6} \mathrm{~m}^{3} / \mathrm{ha}$. Th1s volume per unit area compares favorably with all regions in Canada except some of the high volume conifer forests of the west. All the forest in these three provinces are considered accessible and although the authors suggest there may be some problems with the methods of calculating AAC, softwood reserves in both NB and NS show a deficit -- the only area in Canada where this is even suggested (Table 3 ).

Again due to the influence of the Great Lake Forests, non-pulp hardwoods play an important role in these forests and the authors estimate only $70 \%$ of the volume is actually removed during logging.

Newfoundland and Labrador are a mixture of Boreal forest, peatlands and other non-forested or stunted forest vegetation. None of the referenced material states whether the data represents just forested areas or whether the entire mosaic of vegetation types is included in the area figures presented. As noted in other portions of this report, this is very important as the storage time, etc. of carbon in peatlands will be very different from that in the mature forest. 
This zone is reported to have $7.4 \times 10^{6}$ ha of matcure forest with a gross merchantable volume of $579.5 \times 10^{6} \mathrm{~m}^{3}$ or $78.3 \times 10^{6} \mathrm{~m}^{3} / \mathrm{ha}$ (Table 3 ). Most of the volume is in softwood species and most is considered accessible in Newfoundland but none is economically accessible in Labrador at this time. The MAI for this zone is $1.41 \mathrm{~m}^{3} / \mathrm{ha} /$ year, similar to other more equitable regions in the boreal forest. The merchantable volume is $92 \%$ softwood species and the average harvest is moderately low compared to the AAC. However, if better estimares of depletions due to insects and fire were included. the estimates of $50 \%$ remaining each year could be decreased substantially.

\section{Regional Summary}

Table 7 is a summation of the U.S. and Canadian statistics on area and volume of mature timber, and bole volume per hectare for each vegetation formation or subdivision. Western forests, West Coast/Douglas-fir, Western Pine, California and the Rocky Mountains, all show volumes per unit area greater than any eastern or northern forest. The lower than average value for the Deciduous Forest and the Great Lakes Forest is due in part to the large areas of young forest compured to the west, and the Deciduous Forest, as defined in this report, includes the Central States Region, an area of sparse stocking and low volumes. 
Table 7. Timber volume in the major vegetation formations or ecosystem types in North America.

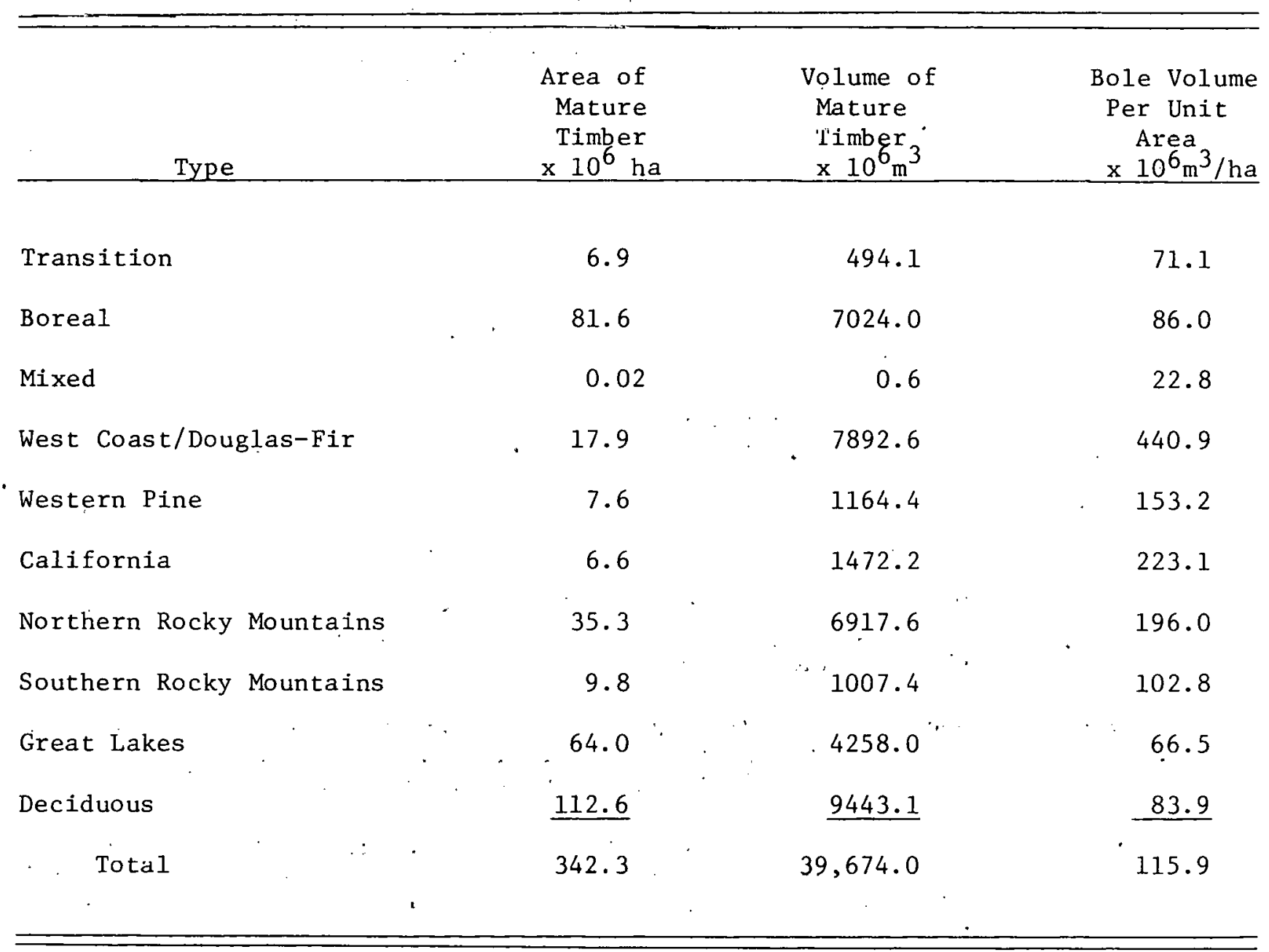


The Influence of Civilization Upon

European and Asian Forests*

\begin{tabular}{|c|c|c|c|}
\hline Date & Location & Event & $\underline{\text { Reference }}$ \\
\hline $\begin{array}{l}9000- \\
5000 \mathrm{BC}\end{array}$ & $\begin{array}{l}\text { Southwest } \\
\text { Asia }\end{array}$ & $\begin{array}{l}\text { Period of early agricultural and postoral } \\
\text { modification. }\end{array}$ & $\begin{array}{l}\text { Naveh \& Dan } \\
(1973)\end{array}$ \\
\hline $\begin{array}{l}5000 \mathrm{BC}- \\
640 \mathrm{AD}\end{array}$ & $\begin{array}{l}\text { Southwest } \\
\text { Asia }\end{array}$ & $\begin{array}{l}\text { Period of widespread and intensive agricultural } \\
\text { modification by clearing, cultivation of arable } \\
\text { lands, and cutting, burning and lumbering of up- } \\
\text { land forests. }\end{array}$ & $\begin{array}{l}\text { Naveh \& Dan } \\
(1973)\end{array}$ \\
\hline $2600 \mathrm{BC}$ & $\begin{array}{l}\text { Southwest } \\
\text { Asia. }\end{array}$ & $\begin{array}{l}\text { First recorded harvest of large timber (chiefly } \\
\text { Cupressus) by Phoenicians; most went to Egypt, } \\
\text { Mesopotamia. }\end{array}$ & $\begin{array}{l}\text { Mikese11 } \\
(1968)\end{array}$ \\
\hline $1127 \mathrm{BC}$ & $\mathrm{Cr}_{\text {ina }}$ & End of 1500 years of forest destruction. & Lin (1956) \\
\hline $\begin{array}{l}1127- \\
255 \mathrm{BC}\end{array}$ & China & $\begin{array}{l}\text { Forestry policy instituted during the Chow } \\
\text { Dynasty. }\end{array}$ & Lin (1956) \\
\hline $255 \mathrm{BC}-$ & China & $\begin{array}{l}\text { Reversal of gains made during Chow Dynasty; } \\
\text { forests gradually reduced to } 9 \% \text { of total land area. }\end{array}$ & Lin (1956) \\
\hline $\begin{array}{l}200- \\
400 \text { AD }\end{array}$ & Italy & $\begin{array}{l}\text { Invasion of Roman Empire by barbarians causes } \\
\text { reforestation of many cultivated areas. }\end{array}$ & $\begin{array}{l}\text { Giordano } \\
(1956)\end{array}$ \\
\hline $\begin{array}{l}400- \\
500 \mathrm{AD}\end{array}$ & England & $\begin{array}{l}\text { Much of England converted from forest to crop- } \\
\text { land and pasture by the Saxons (continuing } \\
\text { through Middle,Ages). }\end{array}$ & Tansley \\
\hline $640 \mathrm{AD}-$ & $\begin{array}{l}\text { Southwest } \\
\text { Asia }\end{array}$ & $\begin{array}{l}\text { Approximate beginning of the conversion of much } \\
\text { of land into desert, badland and swamp as a result } \\
\text { of pastoral nomadism and political stability. }\end{array}$ & $\begin{array}{l}\text { Naveh \& Dan } \\
(197 \dot{3})\end{array}$ \\
\hline $\begin{array}{l}900- \\
1200 \mathrm{AD}\end{array}$ & Germany & $\begin{array}{l}\text { Fuurfold increase in population and large forest } \\
\text { clearing. Similar trends prevail south and east } \\
\text { of Germany. Forest management attempted in city of } \\
\text { Vienna }(1100) \text {. }\end{array}$ & $\begin{array}{l}\text { Heske (1938) } \\
\text { Teclaff } \\
(1956)\end{array}$ \\
\hline $\begin{array}{l}1000- \\
1400\end{array}$ & $\begin{array}{l}\text { Alps, } \\
\text { Appenines }\end{array}$ & Large forest losses from excessive cutting wars. & $\begin{array}{l}\text { Giordano } \\
(1956)\end{array}$ \\
\hline $\begin{array}{l}1000- \\
1400\end{array}$ & $\begin{array}{l}\text { Northwest } \\
\text { Europe }\end{array}$ & $\begin{array}{l}\text { Conversion of extensive areas of formerly deciduous } \\
\text { forest (primarily oak) to moorland by cutting, } \\
\text { burning, grazing and climatic deterioration. Con- } \\
\text { version continued at least through the } 19 \text { th century. }\end{array}$ & $\begin{array}{l}\text { Spurr \& Vaux } \\
\text { (1973) } \\
\text { Walter (1973) } \\
\text { Bolin (1977) }\end{array}$ \\
\hline 1450 & Germany & $\begin{array}{l}\text { Present balance between arable land and forest } \\
\text { reached in west and central Germany. Large-scale } \\
\text { clearing continues in east Germany and Austria } \\
\text { through the } 18 \text { th century. }\end{array}$ & Heske (1938) \\
\hline
\end{tabular}

* Table prepared by T. V. Armentano. 


$\begin{array}{ll}\Gamma^{-2} & \text { Location } \\ 1500- & \text { Western } \\ 1700 & \text { Europe }\end{array}$

17 th \& Scotland 18 th Cent.

$\begin{array}{ll}1789- & \text { France } \\ 1793 & \\ 1821 & \text { Germany } \\ & \\ 1878 & \begin{array}{l}\text { East-central } \\ \text { Europe }\end{array}\end{array}$

1878- Germany

1913

World Europe

War I

World Europe,

War II

1946- Europe

1950

$1950-$
Event

$\underline{\text { Reference }}$

Increasing demand for wood for smelting and

Tansley

glass blowing causes further forest deterioration.

In England much of remaining forest converted to

coppice. General wood shortage reported in England.

Major forest clearing begins in response to charcoal/ Tansley

fuel demands.

Over $3.2 \times 10^{6}$ ha of forest cleared.

Fischer

(1960)

Heske (1938)

Large-scale successful forestry programs undertaken. Timber production nearly doubled over next 75 years.

Most of forests subject to centralized forestry management by the Austro-Hungarian Empire. Many of these policies continued after fall of empire in 1919 .

Increase of over 350,000 ha of forest 1 and.

Heske (1938)

Caused widespread forest devastation and excessive harvesting throughout Europe. Effects of reduction of growing stock in some countries still apparent in 1950 's.

Heavy damage throughout Europe. Under German occupation, cutting was 2 to. 3 times beyond sus $\overline{6}$
tained yield throughout. Germany lost $210 \times 10 \mathrm{~m}^{3}$ tained yield throughout. Germany lost $210 \times 10$
through excessive felling before and during the war. Germany destroyed $20 \times 10^{6}$ ha of USSR forest.

Teclaff (1956)

(Severa1)

(Severa1)

Allied reconstruction and occupation takes $141 \mathrm{x}$ $10^{6} \mathrm{~m}^{3}$ of German timber. Control of forestry policies in east-central Europe (except Austria) taken over by USSR. Five-year plans for reforestation developed (success?).

Large-scale reforestation programs undertaken in China, Korea, parts of Europe (success?).
(Severa1)

(Severa1) 